\title{
Improving resource efficiency and environmental impacts through novel design and manufacturing of disposable baby diapers
}

DOI:

10.1016/j.jclepro.2018.11.046

\section{Document Version}

Accepted author manuscript

Link to publication record in Manchester Research Explorer

Citation for published version (APA):

Mendoza, J. M. F., Popa, S. A., D'aponte, F., Gualtieri, D., \& Azapagic, A. (2019). Improving resource efficiency and environmental impacts through novel design and manufacturing of disposable baby diapers. Journal of Cleaner Production, 210, 916-928. https://doi.org/10.1016/j.jclepro.2018.11.046

Published in:

Journal of Cleaner Production

\section{Citing this paper}

Please note that where the full-text provided on Manchester Research Explorer is the Author Accepted Manuscript or Proof version this may differ from the final Published version. If citing, it is advised that you check and use the publisher's definitive version.

\section{General rights}

Copyright and moral rights for the publications made accessible in the Research Explorer are retained by the authors and/or other copyright owners and it is a condition of accessing publications that users recognise and abide by the legal requirements associated with these rights.

\section{Takedown policy}

If you believe that this document breaches copyright please refer to the University of Manchester's Takedown Procedures [http://man.ac.uk/04Y6Bo] or contact uml.scholarlycommunications@manchester.ac.uk providing relevant details, so we can investigate your claim.

\section{OPEN ACCESS}




\title{
Improving resource efficiency and environmental impacts through novel design and manufacturing of disposable baby diapers
} Joan Manuel F. Mendoza ${ }^{1,{ }^{*}}$, Simona Andreea Popa ${ }^{1}$, Francesco D'Aponte $^{2}$, Diego Gualtieri ${ }^{2}$ and
Adisa Azapagic ${ }^{1^{*}}$

${ }^{1}$ Sustainable Industrial Systems, School of Chemical Engineering and Analytical Science, The Mill, The University of Manchester, Sackville Street, M13 9PL Manchester, United Kingdom

${ }^{2}$ Fameccanica.Data SpA, Via Volta 10, 65129 Pescara, Italy

${ }^{*}$ Corresponding authors: adisa.azapagic@manchester.ac.uk; joanmanuel.fm@gmail.com.

\begin{abstract}
The annual market demand for disposable baby diapers exceeds 20 billion units (690 kt) in the European Union (EU). Almost 40,000 disposable diapers are used every minute, producing 1.3 $\mathrm{t} / \mathrm{min}$ (dry weight) of waste. Based on the estimates in this work, this requires $90.3 \mathrm{PJ}$ of primary energy and emits $2.7 \mathrm{Mt} \mathrm{CO}_{2}$ eq. annually. In an attempt to reduce resource, waste and environmental impacts associated with diapers, this paper focuses on novel design and manufacture of disposable baby diapers. This involves using optimised absorbent core and novel bonding technologies to replace conventional gluing of diaper materials. Life cycle assessment has been performed to compare the environmental performance of these new diapers, here termed "glueless", with standard designs. The annual resource consumption and environmental impacts of glueless diapers have been estimated at different production levels: a single production platform, an industrial plant, a country (Italy) and the EU, taking into account different production volumes, electricity mixes and waste management options. Different market penetration scenarios have been considered to determine potential environmental implications at the EU level by 2020. The results reveal that glueless diapers reduce the consumption of raw materials by $23 \%(9.2 \mathrm{~g} / \mathrm{diaper})$, primary energy demand by $25 \%$ (752 kJ/diaper) and global warming potential by $10 \%\left(10.4 \mathrm{~g} \mathrm{CO}_{2}\right.$ eq./diaper) compared to the standard diapers. They also have more than $50 \%$ lower eutrophication, ozone depletion and human and eco-toxicity. Up to 16 PJ primary energy and $191,000 \mathrm{t} \mathrm{CO}_{2}$ eq. would be saved annually in the EU by using glueless diapers. The cumulative savings would amount to $47 \mathrm{PJ}$ and $566,000 \mathrm{t} \mathrm{CO}_{2}$ eq. by 2020 . The annual consumption of raw materials at the EU level would be reduced by 196,000 $t$ with cumulative savings of up to $584,000 \mathrm{t}$ by 2020 , also reducing the equivalent amount of waste from the disposal of diapers. Consequently, glueless diapers can contribute to meeting the energy, climate and resource efficiency goals specified in the EU 2020 strategy.
\end{abstract}

Keywords: Absorbent hygiene products; Cleaner production; Energy efficiency; Life cycle assessment; Resource efficiency; Waste management.

\section{Nomenclature}

ADL: Acquisition and distribution layer

$A D P_{e}$ : Abiotic depletion potential of elements

ADP $_{\mathrm{f}}$ : Abiotic depletion potential of fossil fuels

AHP: Absorbent hygiene products

AP: Acidification potential

ATB: Air-trough bonded nonwoven

EP: Eutrophication potential

EU: European Union

FAETP: Freshwater aquatic ecotoxicity potential

GHG: Greenhouse gases

GWP: Global warming potential

HTP: Human toxicity potential
LCA: Life cycle assessment

MAETP: Marine aquatic ecotoxicity potential

NW: Nonwovens

OAC: Optimised absorbent core

ODP: Ozone layer depletion potential

PED: Primary energy demand

POCP: Photochemical oxidants creation

potential

SAP: Superabsorbent polymer

SI: Supporting Information

TETP: Terrestrial ecotoxicity potential 


\section{Introduction}

Disposable baby diapers are single-use products designed to optimise babies' urine and faeces reception, absorption and retention, while providing baby's comfort, including skin hygiene, and carer convenience (EDANA, 2005). Today, it is estimated that over 95\% of families in Europe use disposable diapers for their babies (EDANA, 2015). Babies are heavily dependent on diapers during the first 2.5 years of life, using an average of 4.16 disposable diapers per day (Environment Agency, 2008). This corresponds to a consumption of 3,796 units during the diapering period. Thus, almost 21 billion baby diapers are consumed annually in the European Union (EU) alone, corresponding to a market value of $€ 5$ bn (EDANA 2011). Therefore, disposable baby diapers contribute to both the social welfare (quality of life) and economic development. However, they also represent a significant source of resource consumption, waste and environmental impacts.

According to EDANA (2015), the weight of an average disposable baby diaper currently available on the market is equivalent to $33.3 \mathrm{~g}$. As a result, almost 700,000 tonnes of raw materials are consumed annually in the EU to manufacture diapers, not considering packaging and production waste. These products are used just once for a short period of time before they become waste. Accordingly, almost 40,000 disposable diapers are used every minute in the EU, generating 1.3 $\mathrm{t} / \mathrm{min}$ of waste (dry weight). Used diapers are generally disposed of with household waste, comprising about $3 \%$ of the annual EU municipal solid waste generation (EDANA, 2008; Colon et al., 2010; Weisbrod and Van Hoof, 2012). Thus, used diapers end up in waste incineration plants and landfills (JRC, 2013). This represents an important loss of material resources as well as a source of environmental pollution.

Over the last 30 years, the weight of an average disposable baby diaper has been reduced by nearly $50 \%$, decreasing life cycle environmental impacts from $38 \%$ (global warming potential) to $71 \%$ (abiotic depletion of elements) (Cordella et al., 2015). This has been achieved through the reduction in the thickness of nonwoven films and by decreasing the fluff (cellulose) pulp content. This in turn has been enabled by the introduction of superabsorbent polymers (SAP) used to build the absorbent core of the diapers (EDANA, 2015).

Nevertheless, disposable baby diapers still represent a significant source of environmental impacts, particularly due to their growing demand. Based on the data in Cordella et al. (2015), we estimate that their consumption in the EU requires $93.3 \mathrm{PJ}$ primary energy and generates $2.73 \mathrm{Mt}$ $\mathrm{CO}_{2}$ eq. annually. The latter is equivalent to $82 \%$ of annual greenhouse gas (GHG) emissions of an entire country, such as Malta (Eurostat, 2016a), whereas the embodied energy in the products corresponds to the annual final energy consumption by a whole residential sector in countries such as Bulgaria, Croatia or Bosnia and Herzegovina (Eurostat, 2016b).

Thus, researchers have started to evaluate complementary strategies for improving the environmental performance of baby diapers. For instance, Clancy et al. (2013) and Mirabella et al. (2013) analysed the environmental implications of the use of alternative (bio) materials in diaper manufacturing. Other authors investigated the technical and environmental aspects of encouraging post-consumer waste recycling (Arena et al. 2016) and composting (Colon et al., 2010; EspinosaValdemar et al., 2014). However, there are various challenges associated with these strategies, such as environmental burden shifting (bio-based and reusable diapers) and constraints in the quality of the compost as well as the cost-effectiveness and marketability of recycled products (post-consumer composting and recycling). Therefore, further research is required to validate the environmental and socio-economic feasibility of these strategies. In the meantime, product lightweighting and materials optimisation remain the most promising options to keep improving the resource efficiency and environmental performance of disposable diapers (EDANA 2015). These suggestions are also supported by previous relevant life cycle assessment (LCA) studies of baby diapers, such as Sauer et al. (1994), Environment Agency (2008) and Weisbrod and Gert Van Hoof (2012).

The absorbent core of the products (fluff pulp and SAP blend) is the thickest, heaviest and most important part of the diapers because it determines the product performance in terms of fluid 
absorption and retention. The absorbent core accounts for $65 \%$ of the weight of an average baby diaper, with the fluff pulp/SAP ratio equivalent to 40/60 (EDANA, 2015). However, the market is demanding diapers with less fluff pulp content. Consequently, there is a potential for further reducing fluff pulp consumption without necessarily increasing SAP requirements. In fact, due to the absorption and retention properties of SAP, it would be even possible to manufacture diapers without using fluff pulp at all (Nonwovens Industry, 2016). This presents a significant opportunity, given that fluff pulp contributes between $29 \%$ (global warming potential) to $80 \%$ (eutrophication potential) to the environmental impacts related to the diapers' raw materials (Cordella et al., 2015).

A further improvement opportunity lies in on material bonding. Currently, almost all the material layers of a disposable baby diaper are bonded together using hot-melt adhesive, a petrol-based glue. Although glue accounts for a small share of the products' weight $(\approx 3 \%)$, it is an important element in diaper manufacturing as it holds together the constituent parts of the product. Despite the small amount per product, the high consumption of diapers in the EU means that 25,200 tonnes of glue are consumed annually. In addition to material resources, glue-based bonding of diaper materials is an energy intensive process, involving glue melting and pumping through tempered pipes to glue applicators at different points in the manufacturing line. Additionally, maintenance requirements in diaper manufacturing are highly influenced by glue contamination during the process. Glue applicators have to be cleaned using solvents as well as vacuuming residual dust from raw materials between production cycles. Consequently, the time spent on gluerelated maintenance affects the efficacy and cost efficiency of the process and increases its environmental impacts, including global warming potential and human toxicity.

However, the literature related to baby diapers has so far overlooked the potential resource and environmental benefits of optimising the absorbent core and removing the glue. This is the topic of this paper which focuses on related innovations by Fameccanica SpA, a world-leading manufacturer of production machines for diapers. Through the development of a combination of novel alternative bonding technologies, Fameccanica have successfully demonstrated that the use of glue can be completely eliminated or significantly reduced. A further innovation is related to fluff pulp consumption which is reduced considerably by optimising the design of the absorbent core of baby diapers. The environmental implications of these innovations have been estimated using LCA at four different levels: a production platform, an industrial plant, a country (Italy) and the EU. Different market penetration scenarios are considered to determine the potential cumulative resource and environmental implications by 2020 at the EU level. The latter is aimed at providing an insight into the potential contribution of the "glueless" diapers to meeting the energy, climate change and resource efficiency goals defined in the EU 2020 strategy (EC, 2010; EC, 2011).

\section{Methods}

The life cycle environmental impacts of standard and glueless diapers have been estimated following the guidelines in the ISO 14040 and 14044 standards (ISO 2006a, 2006b), as detailed in the next sections.

\subsection{Goal and scope of the study}

The main goal of the study is to estimate the resource consumption and environmental impacts associated with the production of glueless diapers with optimised adsorbent core (OAC) and to compare them to standard diapers. A further aim is to consider the impacts at different levels, from a single production platform up to the EU level. As indicated in Figure 1, the scope of the study is from cradle to grave, excluding the use of diapers, as that is common to both types of product.

The functional unit is defined as the manufacture of 1,000 disposable baby diapers using a P10 production platform. This functional unit has been selected as this is the production capacity of the P10 production platform per minute (Fameccanica, 2016). Therefore, the definition of the functional unit is consistent with the production technology analysed, which is also representative of the European market. 


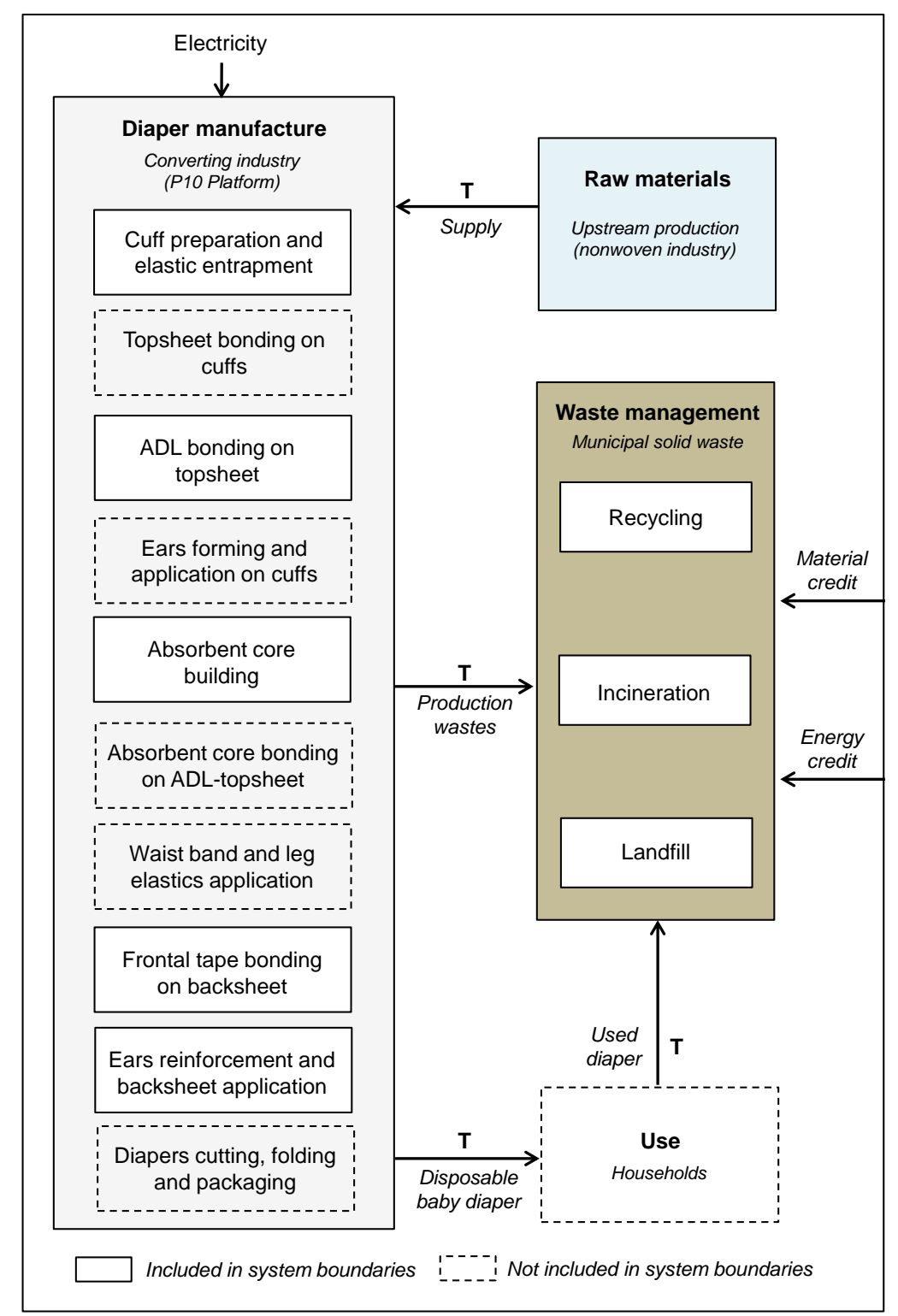

Figure 1 Scope of the study and system boundaries for the glueless and standard diapers ( $\mathrm{T}$ : transport)

\subsection{Inventory data}

\subsubsection{System description}

The standard design of disposable baby diapers is based on a layered construction using different nonwoven (NW) fabrics and various materials, including SAP, cellulose pulp, films, elastics, adhesives and other minor synthetic elements. Their function is to distribute, absorb and retain the excreta (EDANA, 2008). Table 1 details the material composition of a standard diaper. The NW fabrics are flat, porous sheets made of plastic fibres, molten plastic or plastic film. These sheets are bonded together by entangling fibres or filaments and by perforating films, mechanically, thermally or chemically. SAPs are granular crosslinked sodium polyacrylates that can absorb up to 300 times their own weight of aqueous fluids. Fluff pulp is the common name for wood pulps used to provide appropriate bulk, porosity, dry and wet strength, softness and water distribution and absorption (EDANA, 2015, 2008, 2005). All the different layers and components indicated in Table 1 (a to i) are included within the system boundaries, with the exception of the fastening tapes of the back ears (e), the waist and leg elastics ( $\mathrm{g}$ ) and the lotions, inks and dyes (optional elements). All these elements represent less than $1 \%$ of the product weight and they are not affected by the manufacturing innovations considered here. Thus, they have been excluded from the estimates. 
Table 1 Material composition of a standard disposable baby diaper.

\begin{tabular}{|c|c|c|}
\hline Diaper layout & Layers and components & Material composition \\
\hline & a. Nonwoven cuffs & Polypropylene fibres \\
\hline & b. Elastic threads & $\begin{array}{l}\text { Lycra, Spandex, thermoplastic polyurethane, natural and synthetic } \\
\text { rubber or polyester foam }\end{array}$ \\
\hline & c. Nonwoven topsheet & $\begin{array}{l}\text { Polypropylene and polyethylene fibres, masterbach pigment and } \\
\text { surfactant }\end{array}$ \\
\hline & $\begin{array}{l}\text { d. Acquisition and distribution } \\
\text { layer (nonwoven) }\end{array}$ & Polypropylene, polyethylene and polyester fibres \\
\hline & $\begin{array}{l}\text { e. Front ears (nonwoven) and } \\
\text { back ears (nonwoven and } \\
\text { fastening tapes) }\end{array}$ & $\begin{array}{l}\text { Polypropylene fibres (front ears) } \\
\text { Polypropylene fibres and elastomer (back ears) }\end{array}$ \\
\hline & f. Absorbent core & $\begin{array}{l}\text { Polypropylene and polyethylene fibres, masterbach pigment and } \\
\text { surfactant (upper and lower tissues) } \\
\text { Superabsorbent polymer and elemental chlorine free (ECF) bleached } \\
\text { fluff pulp }\end{array}$ \\
\hline & g. Waist band and leg elastics & $\begin{array}{l}\text { Lycra, Spandex, thermoplastic polyurethane, natural and synthetic } \\
\text { rubber or polyester foam }\end{array}$ \\
\hline & h. Composite backsheet & $\begin{array}{l}\text { Low density polyethylene and calcium carbonate (polymer film) } \\
\text { Polypropylene and polyethylene fibres and masterbach pigment (nonwoven) }\end{array}$ \\
\hline & i. Nonwoven frontal tape & Polypropylene fibres \\
\hline
\end{tabular}

The diaper components, produced upstream, are cut, shaped and bonded in the diaper manufacturing process to build up an effective multi-layer structure. The process starts by cutting a NW fabric into two strips of material called cuffs (a in Table 1). Elastics threads (b) are applied on the internal part of each cuff which are folded in order to encapsulate the elastics. The cuffs act as barriers to avoid fluid leaks. Once the cuffs have been prepared, a very thin NW fabric, called topsheet (c), is glued to them. The topsheet is highly permeable to minimise the time that the fluid is in contact with the skin of the baby (EDANA, 2005). An acquisition and distribution layer (ADL) is glued onto the upper central part of the topsheet. The ADL (d) stores the fluid temporarily before it is transferred and distributed through capillaries to the absorbent core (JRC, 2013). Subsequently, the front and back ears (e) are formed and glued to the cuffs. The function of the ears is to fasten and secure the diaper to the body of the baby. Also, they facilitate closing of the product after use. In parallel, the absorbent core (f) is built. It is a fluid storage made up of an appropriate blend of fibrous fluff pulp and SAP encapsulated between two NW layers, known as upper tissue and lower tissue. The absorbent core is the thickest and heaviest part of this multi-layer construction and the key component of diapers because it absorbs and retains the fluid (EDANA, 2008). Once built, the absorbent core is glued to the ADL-topsheet layers. Finally, an outer layer, called backsheet (h), seals the whole construction acting as a fluid-impervious barrier. The backsheet can be made up of a single-material or a NW and film composite that should be breathable in order to protect the skin of the baby against irritations or infections (EDANA, 2005). A piece of frontal tape (i) is later attached to it for the diaper to be closed after use. Before the backsheet is glued to the cufftopsheet-core construction, further elastics $(\mathrm{g})$ are applied to ensure proper fit of the diaper to the baby's waist and legs. Additionally, glue is applied on the backsheet perimeter to reinforce the ears attachment. Once all the layers of materials have been glued, the diapers are cut into individual pieces, folded and packed for shipping.

Diaper manufacturing is a continuous automated process. Material layers are cut, shaped (or formed) and bonded in several production modules using different technologies. As mentioned earlier, almost all the layers of materials are bonded together using glue. To enable the bonding, 
the solid glue is first melted in a fuser at a temperature of $130-170^{\circ} \mathrm{C}$. The hot-melt glue is then pumped through a system of tempered pipes to glue applicators placed in different production modules of the P10 platform. Various equipment is used in the gluing process, including fusers, pumps, pipes and glue applicators. Chiller units are also needed to avoid glue contamination in some unit processes.

However, glue bonding can be completely avoided or notably reduced by using alternative bonding technology in five crucial unit processes (Figure 1): elastics entrapment by cuffs, ADL application on the topsheet, absorbent core building, frontal tape application on backsheet and ears reinforcement. This involves the use of thermal, ultrasonic and thermo-mechanical bonding and has no negative effects on the final product. However, elimination of glue in other unit processes and product layers could compromise the performance of the diapers during use. As a result, only the five unit processes where glue can be removed from the manufacturing process are included within the system boundaries of the study, alongside the process and household wastes as well as transportation in the life cycle of diapers.

The innovations in the production of glueless diapers include a combination of raw materials and bonding pattern selection, design of an optimised quilted absorbent core, technology design and development and process engineering and optimisation. For instance, a quilted absorbent core was designed to bond the upper and lower tissues thermo-mechanically, which entailed the reengineering and optimisation of the pad-forming drum. In the standard process, the surface of the pad-forming drum is flat, whereas in the glueless process it has a number of dots used to create areas where the pad is not formed so that the NW tissues of the pad can be bonded thermomechanically. However, an air-trough bonded (ATB) nonwoven should be also incorporated in the glueless quilted absorbent core to entrap SAP particles and preserve the core integrity. Additionally, the material optimisation of the diapers' absorbent core by changing the fluff pulp/SAP ratio from $40 / 60$ to $20 / 80(\mathrm{w} / \mathrm{w})$ entailed the development of a new SAP injection and forming chamber system to control better the SAP and fluff pulp mixture.

\subsubsection{Data and assumptions}

The inventory data for the standard and glueless diapers are detailed in Table 2 and in Tables S1 and $\mathrm{S} 2$ in the Supporting Information (SI). The data on the use of raw materials and the diaper manufacturing process have been provided by Fameccanica, corresponding to year 2016. The LCl data on transport requirements and waste management from gate-to-grave have been calculated as described in section 2.3. The background data are from the GaBi database v6.1 (Thinkstep, 2016); Ecoinvent v2.2 has been used to fill any data gaps (SCLCI, 2010). The inventory data for different life cycle stages are discussed below.

\subsubsection{Raw materials}

The amount of raw materials corresponds to a typical diaper design for six to 12 month-old babies. The net weight of a single standard diaper is equivalent to $39.8 \mathrm{~g}$, which is within the range of disposable diapers available on the market (JRC, 2013); this includes material losses of $1 \%$ in the production process. The net weight of a glueless diaper is $30.7 \mathrm{~g}$, which represents a weight reduction of $23 \%$ on the standard product. The OAC itself has $30 \%$ lower material requirements than the absorbent core of the standard diaper. Furthermore, the OAC with a fluff pulp/SAP ratio of $20 / 80$ entails a $76 \%$ reduction in the fluff pulp weight while also reducing the SAP content by $7 \%$. Additionally, the use of alternative bonding reduces net glue requirements by $66 \%(0.63 \mathrm{~g} /$ diaper). Finally, process re-engineering for glueless elastics entrapment by cuff reduces slightly $(1 \%)$ the amount of NW required in the process. All these reductions in the raw materials lead to a proportional reduction in packaging requirements and waste generation.

Due to a lack of data, the environmental impacts of raw materials processing have been determined by considering their composition (Table 1 ) and weight (Table 2). Thus, the energy data for their production are excluded. Only the SAP processing data are considered based on data from Gontia (2014). 
Table 2 Inventory data for 1,000 standard and glueless diapers.

\begin{tabular}{|c|c|c|c|c|}
\hline Life cycle stage & Component & Element & Standard & Glueless \\
\hline \multirow[t]{16}{*}{ Raw materials } & \multirow[t]{2}{*}{ Elastic cuffs } & Nonwoven (NW) cuff (kg) & 1.16 & 1.15 \\
\hline & & Elastics $(\mathrm{kg})$ & 0.02 & 0.02 \\
\hline & \multirow{6}{*}{$\begin{array}{l}\text { Topsheet-ADL } \\
\text { construction } \\
\text { Absorbent core }\end{array}$} & NW topsheet $(\mathrm{kg})$ & 1.03 & 1.03 \\
\hline & & $\mathrm{ADL}^{\mathrm{a}}(\mathrm{kg})$ & 1.89 & 1.89 \\
\hline & & Upper and lower tissues (kg) & 1.19 & 1.19 \\
\hline & & Fluff pulp (kg) & 12.71 & 3.03 \\
\hline & & $\operatorname{SAP}^{\mathrm{D}}(\mathrm{kg})$ & 15.15 & 14.14 \\
\hline & & Air-through bonded layer (kg) & - & 2.11 \\
\hline & \multirow{5}{*}{$\begin{array}{l}\text { Front and elastic back } \\
\text { ears } \\
\text { Composite backsheet } \\
\text { with frontal tape }\end{array}$} & Elastic NW for back ears $(\mathrm{kg})$ & 1.55 & 1.55 \\
\hline & & NW for front ears $(\mathrm{kg})$ & 0.26 & 0.26 \\
\hline & & NW backsheet $(\mathrm{kg})$ & 2.24 & 2.24 \\
\hline & & Backsheet film (kg) & 1.88 & 1.88 \\
\hline & & Frontal tape $(\mathrm{kg})$ & 0.20 & 0.20 \\
\hline & \multirow{3}{*}{$\begin{array}{l}\text { Hot-melt adhesive } \\
\text { Packaging }\end{array}$} & Glue $(\mathrm{kg})$ & 0.95 & 0.32 \\
\hline & & Corrugated cardboard $(\mathrm{kg})$ & 0.09 & 0.07 \\
\hline & & Plastic film (kg) & 0.20 & 0.20 \\
\hline \multirow{10}{*}{$\begin{array}{l}\text { Diaper } \\
\text { manufacture }\end{array}$} & Motors & High voltage electricity (MJ) & 3.60 & 3.72 \\
\hline & Vacuum system & $\sim \| \sim$ & 6.58 & 6.59 \\
\hline & Chillers & $\sim \| \sim$ & 0.08 & 0.00 \\
\hline & Glue applicators & $\sim \| \sim$ & 0.86 & 0.12 \\
\hline & Pneumatic unit & $\sim \| \sim$ & 0.90 & 0.00 \\
\hline & Ultrasonic systems & $\sim \| \sim$ & - & 0.08 \\
\hline & Thermo-mechanical unit & $\sim \| \sim$ & - & 0.30 \\
\hline & Heat-sealers & $\sim \| \sim$ & 0.04 & 0.07 \\
\hline & Machinery maintenance & Lubricants (g) & 3.3 & 2.8 \\
\hline & & Solvents $(\mathrm{g})$ & 5.1 & 0.7 \\
\hline \multirow[t]{5}{*}{ Transport } & \multirow[t]{2}{*}{ Raw materials ${ }^{c}$} & Lorry 40 t, 50-2310 km (tkm) & 39.87 & 34.09 \\
\hline & & Ocean freighter, $9250 \mathrm{~km}(\mathrm{tkm})$ & 118.20 & 28.19 \\
\hline & \multirow{3}{*}{$\begin{array}{l}\text { Production waste } \\
\text { Final product } \\
\text { End-of-life waste }\end{array}$} & Lorry $40 \mathrm{t}, 10 \mathrm{~km}(\mathrm{tkm})$ & 0.01 & 0.01 \\
\hline & & Lorry $40 \mathrm{t}, 500 \mathrm{~km}(\mathrm{tkm})$ & 20.11 & 15.50 \\
\hline & & Lorry $40 \mathrm{t}, 50 \mathrm{~km}(\mathrm{tkm})$ & 2.01 & 1.55 \\
\hline \multirow{5}{*}{$\begin{array}{l}\text { Waste } \\
\text { management }\end{array}$} & \multirow[t]{3}{*}{ Production waste } & Recycling, 21\% (kg) & 0.15 & 0.13 \\
\hline & & Incineration, $34 \%(\mathrm{~kg})$ & 0.23 & 0.19 \\
\hline & & Landfill, $45 \%(\mathrm{~kg})$ & 0.31 & 0.25 \\
\hline & \multirow[t]{2}{*}{ Used diapers } & Incineration, 38\% (kg) & 15.13 & 11.67 \\
\hline & & Landfill, $62 \%(\mathrm{~kg})$ & 24.70 & 19.04 \\
\hline
\end{tabular}

a Acquisition and distribution layer.

${ }^{\mathrm{b}}$ Superabsorbent polymer: sodium polyacrylate (for details, see Gontia (2014)).

"Includes all the materials under the "Raw materials" category in this table as well as the lubricants and solvents.

\subsubsection{Diaper manufacture}

Various electrical equipment is used in the manufacture of both standard and glueless diapers, including motors, vacuum systems and heat sealers (Table 2). Glue applicators and chillers are needed for the standard diapers while the glueless process requires ultrasonic and thermomechanical units. Overall, the standard manufacturing process consumes $12 \mathrm{MJ}$ per 1,000 diapers while the glueless has a $9.6 \%$ lower electricity requirements. It should be noted that this consumption refers to the five unit processes considered in the study (Figure 1), rather than the whole manufacturing process; the latter consumes $190 \mathrm{MJ}$ (Cordella et al., 2015).

\subsubsection{Transport}

Transportation is considered from cradle to grave. The raw materials are supplied to Fameccanica's manufacturing plant (in Italy) from different EU countries by road, with the exception of the fluff pulp which is shipped from the US; for details, see Table 2. The distance travelled by the final product from the manufacturing plant to the customer has been estimated based on the data from the Environment Agency (2008). 


\subsubsection{Waste management}

This stage includes management of production waste and used diapers. Production waste comprises raw material losses (1\% of the total amount required per functional unit) and the packaging for the raw materials (corrugated cardboard and plastic film). Following current waste management practice in Italy, the packaging waste is recycled, incinerated with energy recovery and landfilled (see Table 3). Waste nonwovens, elastics and adhesives are incinerated with energy recovery and landfilled. Used diapers, comingled with the rest of the household waste, are also disposed of in this way. Recycling and composting of used diapers is not common practice due to the nature of the product and the current state-of-the-art of these waste management technologies (Cordella et al., 2015). Therefore, these waste management alternatives are not considered.

The environmental credits related to recycling of packaging have been calculated by subtracting the environmental burdens of the production of an equivalent amount of virgin raw material, while including the impacts related to waste recycling. Data provided by Schmidt (2012) for the recycling of plastic scrap were used in the calculations. Based on the fact that the recycled content of cardboard packaging (FEFCO and Cepi, 2012) is almost equivalent to the cardboard recycling share in Italy and the EU (85\%), no environmental credits have been applied for the recycling of cardboard packaging. The environmental credits for waste incineration with energy recovery have been calculated by subtracting the environmental burdens of the production of an equivalent amount of electricity and heat. The environmental credits related to heat production through waste incineration have been calculated using Eurostat (2016d) data on the supply, transformation and consumption of heat in the EU. Table S3 in the SI presents the Italian and EU heat generation mixes.

Overall, the absorbent core building is the most resource intensive stage in the manufacturing of standard diapers. It determines $73 \%$ (29 kg/1,000 diapers) of all material requirements and waste generation, $77 \%$ (9 MJ/1,000 diapers) of energy consumption and $93 \%$ (170 tkm/1,000 diapers) of transport needs for the standard diapers. The optimised absorbent core in the glueless diapers has significantly lower requirements, reducing the amount of raw materials to $20.5 \mathrm{~kg}$, energy to $1.1 \mathrm{MJ}$ and transport to $100 \mathrm{tkm}$ per 1,000 diapers.

\subsubsection{Considering different production levels}

In order to determine the environmental implications of the production of glueless diapers beyond the functional unit of 1,000 diapers, the impacts have been scaled up to the following levels: a production platform, an industrial plant, Italy and the EU, based on the corresponding annual production volumes. A single P10 production platform is assumed to produce 225 million diapers annually. This value assumes two production cycles of $15 \mathrm{~h}$ per day over 250 working days in a year. Each production cycle lasts $8 \mathrm{~h}$, with 1,000 diapers produced per minute. However, the production efficiency is equivalent to $94 \%$. This means that the production is stopped for 30 minutes for maintenance (e.g. cleaning the glue applicator) between production cycles. However, the annual production volume of glueless diapers would be higher due to the lower maintenance requirements related to the elimination of the glue applicators. This is not considered here due to a lack of actual data.

At the plant level, four P10 platforms have been assumed on average, based on data from Fameccanica. Thus, the annual production per manufacturing plant corresponds to 900 million diapers, under the same operating conditions as above. At the national level, the annual production of diapers in Italy is equivalent to $1,797.7$ million diapers and at the EU level to 20,817.5 million (Euromonitor International, 2015). Table 3 summarises the variables used to calculate the environmental impacts of standard and glueless diapers at the levels of Italy and the EU.

Due to a lack of data, technological variations in raw materials processing in space (Italy and the EU) and time (2016 and 2020) are not considered. The environmental impacts of the raw materials used in diaper manufacturing in Italy and the EU are assumed to be equivalent (Table 3).

Euromonitor International (2015) data have been used to model the EU electricity mix. Each EU country is considered to contribute to the EU grid proportionally to the national diaper production 
volume. For instance, around $70 \%$ of the current (and forecast) EU production volume of disposable baby diapers is concentrated in six countries: UK, France, Germany, Poland, Italy and Spain . Thus, the national electricity mixes of these countries are considered to contribute $70 \%$ to the EU grid. For further details, see Tables S4 and S5 in the SI. ENTSO-E $(2015,2016)$ yearly energy data and scenario outlook have been used to model the Italian and EU electricity grid mixes for 2016 and 2020. The transportation requirements are detailed in Table 3 . The Italian and EU waste management scenarios have been defined according to Eurostat (2016c) data on the generation and treatment of packaging and municipal waste (Table 3 ). The avoided electricity production corresponds to the Italian and EU electricity grid mixes for 2016 and 2020.

Table 3 Data and assumptions for glueless diapers in Italy and in the EU.

\begin{tabular}{|c|c|c|c|}
\hline $\begin{array}{l}\text { Life cycle } \\
\text { stage }\end{array}$ & Variable & Italy & EU \\
\hline Raw materials & Inputs & As in Table 2 & As in Table 2 \\
\hline Manufacture & $\begin{array}{l}\text { Production } \\
\text { volume } \\
\text { Electricity mix }\end{array}$ & $\begin{array}{l}1.80 \text { billion diapers }(2016) \\
\text { Italian electricity }(2016)\end{array}$ & $\begin{array}{l}20.8 \text { billion diapers }(2016) \\
21.2 \text { billion diapers }(2020) \\
\text { EU electricity ( } 2016 \text { and } 2020)\end{array}$ \\
\hline Transport & $\begin{array}{l}\text { Raw materials } \\
\text { Final product } \\
\text { Product waste }\end{array}$ & As in Table 2 & $\begin{array}{l}\text { As in Table } 2 \\
1,000 \mathrm{~km} \text { (disposable diaper) } \\
100 \mathrm{~km} \text { (production wastes), } 150 \\
\mathrm{~km} \text { (used diapers) }\end{array}$ \\
\hline $\begin{array}{l}\text { Waste } \\
\text { management }\end{array}$ & $\begin{array}{l}\text { Production } \\
\text { wastes and used } \\
\text { diapers } \\
\text { Packaging }\end{array}$ & $\begin{array}{l}\text { As in Table } 2 \\
\text { Recycling: } 36.8 \% \text { plastic, } \\
84.6 \% \text { cardboard } \\
\text { Incineration: } 36.8 \% \text { plastic, } \\
7.1 \% \text { cardboard } \\
\text { Landfill: } 26.4 \% \text { plastic, } 8.2 \% \\
\text { cardboard }\end{array}$ & $\begin{array}{l}\text { Incineration: } 48.7 \% \text {, landfill: } 45.4 \% \\
\text { Incineration without energy } \\
\text { recovery: } 5.9 \% \\
\text { Recycling: } 36.2 \% \text { plastic, } 83.2 \% \\
\text { cardboard } \\
\text { Incineration: } 29.7 \% \text { plastic, } 7.3 \% \\
\text { cardboard } \\
\text { Landfill: } 34.0 \% \text { plastic, } 9.5 \% \\
\text { cardboard }\end{array}$ \\
\hline
\end{tabular}

\subsubsection{Considering different market penetration of glueless diapers}

In addition to the different production levels, a scenarios analysis has been carried out to consider the effect of different market penetration of the glueless diapers at the EU level in the period 20162020. These scenarios are detailed in Table 4. The Market A scenario (poor uptake) considers implementation of only one P10 glueless production platform per year, equivalent to a market penetration of $6.3 \%$ by 2020 . Market B (low uptake) assumes four P10 glueless production platforms or one industrial plant per year (penetration of $21.2 \%$ by 2020). In Market C (moderate uptake), the production volume of glueless diapers increases by $8.6 \%$ annually (reaching $43.2 \%$ by 2020), equivalent to the annual production volume in Italy. Market D (high uptake) sees the production volume grow to $14 \%$ annually, reaching $70 \%$ of the market share by 2020 . This corresponds to the volumes produced by the abovementioned six market-leading countries (Euromonitor International 2015). Finally, market $E$ (very high uptake) is as a radical scenario where the manufacture of glueless diapers increases by $20 \%$ annually to satisfy $100 \%$ of the EU demand for diapers by 2020.

\subsubsection{Sensitivity analysis}

According to Cordella et al. (2015), the GWP of diapers has been reducing by an average of $1.6 \%$ per year over the period 1987 to 2011 due to the changes in the weight and composition of diapers. This corresponds to a reduction in GWP of about $15 \%$ per decade. The sensitivity analysis, therefore, considers the effect of these reductions on the impacts of glueless diapers over the period from 2016 to 2020. 
Table 4 Scenarios for market penetration of glueless diapers in the EU in the period 2016-2020.

\begin{tabular}{|c|c|c|c|c|c|c|}
\hline Scenarios $^{\mathrm{a}}$ & Variables & 2016 & 2017 & 2018 & 2019 & 2020 \\
\hline Market A & Technology penetration (\%) & 1.1 & 2.2 & 3.2 & 4.3 & 5.3 \\
\hline \multirow[t]{2}{*}{ (“Poor uptake”) } & Production volume (million units) & 225 & 450 & 675 & 900 & 1,125 \\
\hline & P10 production platforms required (units) & 1 & 2 & 3 & 4 & 5 \\
\hline Market B & Technology penetration (\%) & 4.3 & 8.6 & 12.8 & 17.0 & 21.2 \\
\hline \multirow[t]{2}{*}{ (“Low uptake”) } & Production volume (million units) & 900 & 1,800 & 2,700 & 3,600 & 4,500 \\
\hline & P10 production platforms required (units) & 4 & 8 & 12 & 16 & 20 \\
\hline Market C & Technology penetration (\%) & 8.6 & 17.3 & 25.9 & 34.5 & 43.2 \\
\hline ("Moderate & Production volume (million units) & 1,798 & 3,613 & 5,447 & 7,302 & 9,169 \\
\hline uptake") & P10 production platforms required (units) & 8 & 16 & 24 & 32 & 41 \\
\hline Market D & Technology penetration (\%) & 14.1 & 28.2 & 42.3 & 56.4 & 70.5 \\
\hline \multirow[t]{2}{*}{ (“High uptake”) } & Production volume (million units) & 2,937 & 5,902 & 8,898 & 11,928 & 14,978 \\
\hline & P10 production platforms required (units) & 13 & 26 & 40 & 53 & 67 \\
\hline Market E & Technology penetration (\%) & 20.0 & 40.0 & 60.0 & 80.0 & 100.0 \\
\hline (“Very high & Production volume (million units) & 4,164 & 8,368 & 12,616 & 16,911 & 21,236 \\
\hline uptake") & P10 production platforms required (units) & 19 & 37 & 56 & 75 & 94 \\
\hline
\end{tabular}

${ }^{a}$ The annual production volumes related for scenarios A and B have been calculated based on the assumptions described in section 2.2.3. of the paper. The production volumes for $\mathrm{C}, \mathrm{D}$ and $\mathrm{E}$ have been estimated based on the data in Euromonitor International (2015). Market A: low industrial uptake of glueless innovations (5.3\%), Market B: low uptake (21.2\%), Market C: moderate uptake (43.2\%), Market D: high uptake (70.2\%), Market E: very high uptake (100\%).

\subsection{Life cycle impact assessment}

The life cycle environmental impacts of standard and glueless diapers have been calculated according to the CML 2001 method (version 2015) (Guinée et al., 2001). The environmental indicators considered are: abiotic depletion potential of elements $\left(A D P_{e}\right)$, abiotic depletion potential of fossil fuels $\left(A D P_{f}\right)$, acidification potential $(A P)$, eutrophication potential $(E P)$, freshwater aquatic ecotoxicity potential (FAETP), global warming potential (GWP), human toxicity potential (HTP), marine aquatic ecotoxicity potential (MAETP), ozone layer depletion potential (ODP), photochemical oxidants creation potential (POCP) and terrestrial ecotoxicity potential (TETP). In addition, primary energy demand (PED), based on the net calorific value, is also considered. The systems have been modelled in GaBi v7.2 (Thinkstep, 2016).

\section{Results and discussion}

The next section discusses the environmental impacts of standard and glueless diapers for the functional unit of 1,000 units. This is followed in section 3.2 by the impacts at different production levels of glueless diapers. Finally, section 3.3 discusses the resource and environmental implications of different market penetration of glueless diapers and potential savings relative to the standard product.

\subsection{Environmental impacts of standard and glueless diapers}

The results in Figure 2 indicate that glueless diapers are environmentally more sustainable than the standard product reducing the impacts from $1 \%\left(\mathrm{ADP}_{\mathrm{f}}\right)$ to $67 \%(\mathrm{ODP})$; for further details, see Table S6 in the SI. The greatest reductions (>50\%) are achieved for EP, FAETP, HTP, MATEP and ODP. GWP is $10 \%$ lower and PED $25 \%$. These reductions are largely due to the greater material efficiency of glueless diapers which weigh $23 \%$ less than the standard (Table 2). This is a consequence of the raw materials being the key environmental hotspot (Figure 2), contributing from $65 \%$ (EP) to $>95 \%$ (PED) to the impacts of standard diapers. These findings are congruent with previous LCA studies of standard diapers (Environment Agency, 2008; Weisbrod and Van Hoof, 2012; JRC, 2013; EDANA, 2015; Cordella et al., 2015) which also found the raw materials to be the key environmental hotspot.

The raw materials are also the main hotspot for the glueless diapers, with their relative importance being slightly higher than for the standard variety, ranging from $80 \%(G W P)$ to $97 \%\left(A D P_{f}\right)$. This relatively greater contribution of the raw materials for the glueless product is related to the reduced requirements for transport and waste management due to the lower amount of materials used in these diapers. Consequently, the environmental impacts of transport are reduced by $18 \%\left(\mathrm{ADP}_{\mathrm{e}}\right)$ to $75 \%$ (MAETP), whereas the impacts from waste management are $22 \%$ lower (Figure 2 ). 


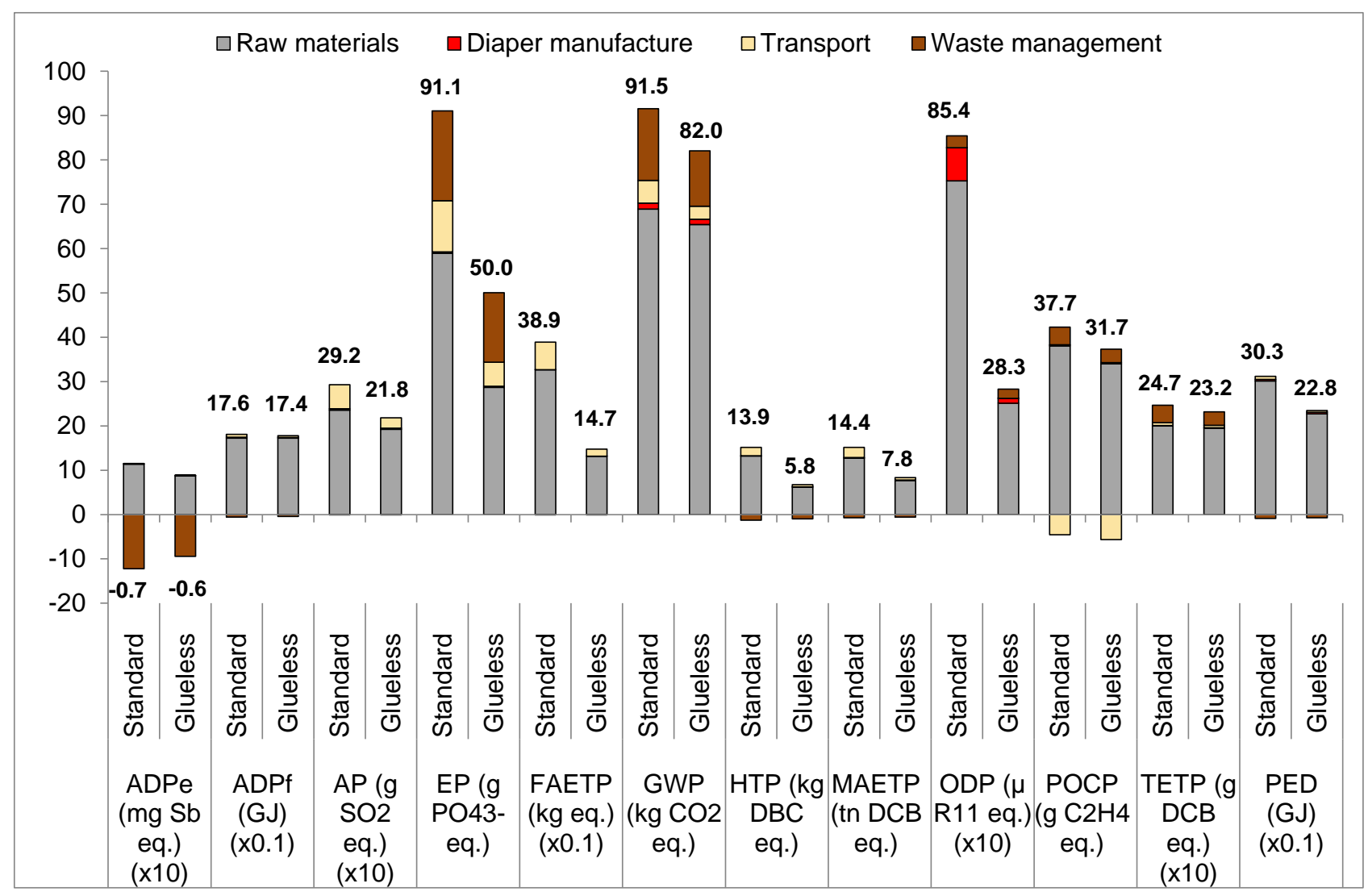

Figure 2 Environmental impacts of 1,000 standard and glueless diapers and contribution of different life cycle stages.

$\left[A D P_{e}\right.$ : abiotic depletion potential of elements; $\mathrm{ADP}_{\mathrm{f}}$ : abiotic depletion potential of fossil fuels; $A P$ : acidification potential; EP: eutrophication potential; FAETP: freshwater aquatic ecotoxicity potential; GWP: global warming potential; HTP: human toxicity potential; MAETP: marine aquatic ecotoxicity potential; ODP: ozone layer depletion potential; POCP: photochemical oxidants creation potential TETP: terrestrial ecotoxicity potential.]

Transport is an important contributor to five impacts for both types of diaper. These are AP (contributing $11 \%$ and $19 \%$ to the standard and glueless, respectively), EP $(11 \%$ and $13 \%)$, FAETP $(11 \%$ and $16 \%)$, HTP $(9 \%$ and $13 \%)$ and MAETP (7\% and $16 \%)$. However, POCP from transport is negative. This is due to the emissions of NO from transport reducing ozone formation and having a negative CML characterisation factor (Thinkstep, 2016) which in this case outweighs the contribution of ozone formation to the POCP.

Waste management is the second most relevant life cycle stage for EP (contributing $22 \%$ and $31 \%$ to the standard and glueless, respectively), GWP (15\% and 18\%), POCP ( 10\% for both types of diaper) and TETP (13\%-16\%). Most of these contributions (87\% to $100 \%)$ are due to landfilling. Recycling and incineration reduce the impacts, most notably $\mathrm{ADP}_{\mathrm{e}}$, which is overall negative for both products (Figure 2).

Diaper manufacturing is the less environmentally-relevant life cycle stage, contributing $<2 \%$ to the impacts, The exception is ODP to which it adds $4 \%$ for the glueless and $9 \%$ for the standard diapers. This is mainly due to the use of solvents to clean the glue applicators (note that glueless diapers still require some gluing; see section 2.2.1 and Table 2). Nevertheless, the new manufacturing process for glueless diapers reduces the impacts from the standard manufacture by $30 \%$ (TETP) to almost 100\% (HTP).

3.1.1. Contribution of raw materials to environmental impacts

Given the importance of the raw materials for the environmental impacts of both types of diaper, this section discusses the main contributing materials. As can be seen in Figure 3, the nonwovens 
(NW) determine between $2.7 \%$ (ODP) and $40.4 \%$ (TETP) of environmental impacts of standard diapers. For the glueless, their contribution ranges from $8.4 \%$ (ODP) to $72.1 \%$ (TETP). The NW impacts are $5 \%$ to 1.7 times higher in glueless diapers due to the use of the ATB layer to build the absorbent core (see Table 2). Nevertheless, the lower consumption of fluff pulp, SAP, glue and packaging compensates for the higher impacts from NW, resulting in the lower total impacts from the raw materials in the glueless diapers.

Fluff pulp and SAP together determine the majority of the impacts from the raw materials (44\%$84 \%)$ for the standard diapers because they also contribute to the majority $(70 \%)$ of their total weight. Due to the reduced use of these two materials in the glueless product, their impacts are 1.2-3.7 times lower than for the standard diapers. Furthermore, glue removal reduces the impacts of materials bonding by $66 \%$. Finally, the contribution of packaging is small for both types, with its impacts being lower by $3.5 \%-12 \%$ for glueless diapers.

The environmental impacts of the backsheet (PE film) and elastics are the same for both product alternatives because these material inputs are not affected by the innovations related to the glueless diapers. For further details on the impacts of the raw materials, see Figures S1-S6 in the SI.

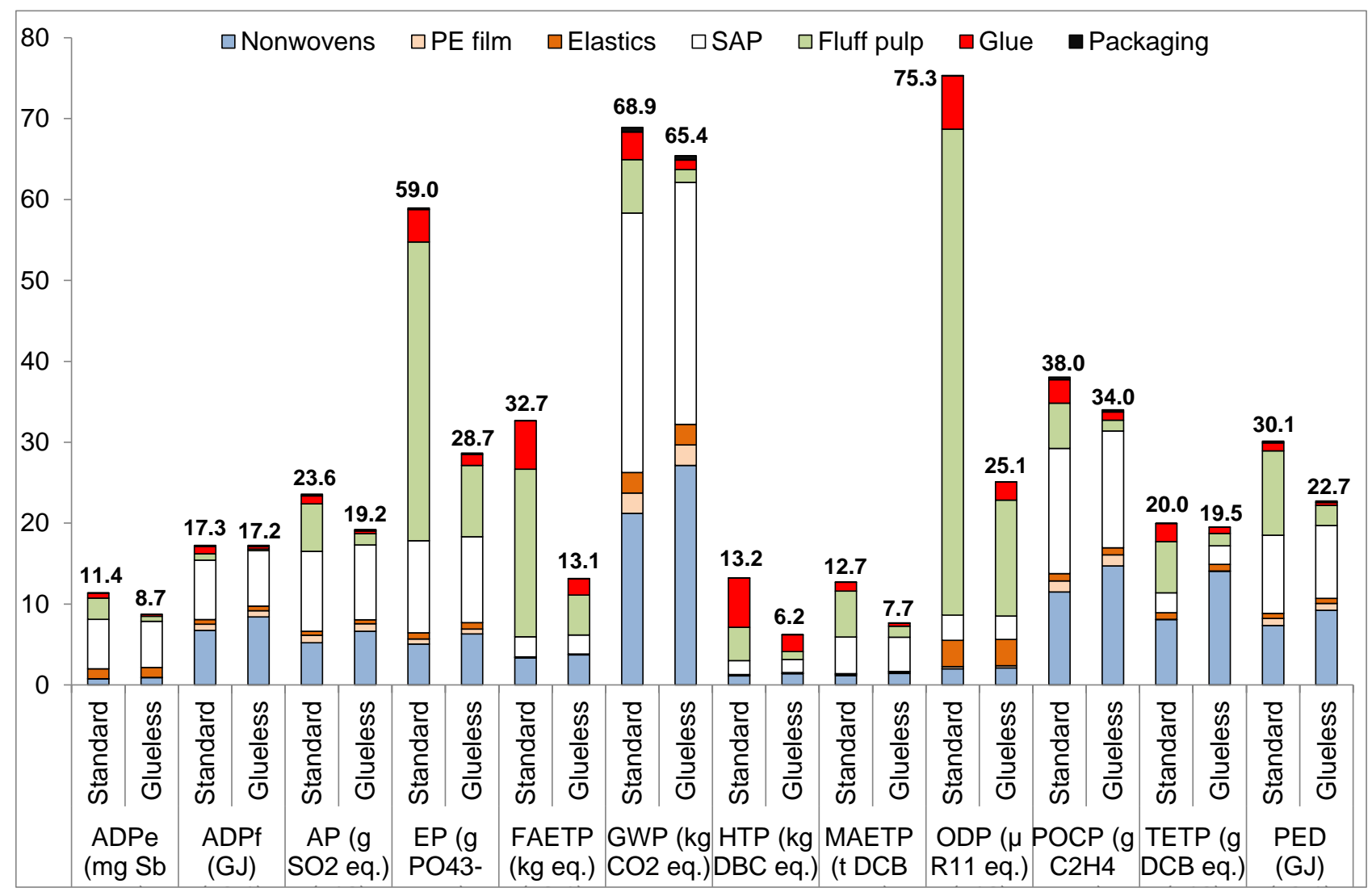

Figure 3 Contribution of raw materials to environmental impacts of standard and glueless diapers. [Impacts expressed per 1,000 diapers. Nonwovens: cuffs, topsheet, acquisition and distribution layer (ADL), upper and lower tissues, air-through bonded (ATB) layer, nonwoven backsheet and front and back ears. PE (polyethylene) film: backsheet. Elastics: elastomers encapsulated by the cuffs and back ears. SAP: superabsorbent polymer Packaging: cardboard and plastic film. For the impacts nomenclature, see Figure 2.]

\subsubsection{Contribution of the manufacturing process to environmental impacts}

Although the manufacturing process is not an environmental hotspot, it is of interest to consider how the impacts of the improved glueless process compare to the standard manufacture. These results are detailed in Figure 4. As can be seen, the vacuum system and the motors are the most energy-intensive equipment in both manufacturing processes. For the standard diapers, they determine $84 \%$ of the total electricity consumption and cause $>80 \%$ of the impacts, with the exception of HTP (68\%), FAETP $(58 \%)$ and ODP $(0.4 \%)$. The glue applicators, including chillers, 
contribute significantly to HTP (25\%), FAETP (36\%) and ODP $(99 \%)$ and $10 \%$ to the rest of the impacts. The impacts from the glue applicators are due to the use of solvents to clean the equipment. The pneumatic unit and heat sealers determine less than $7 \%$ of the impacts, which is equivalent to their share in the electricity consumption.

For the glueless manufacturing process, the impacts of the vacuum system and motors are slightly higher due to the slightly higher electricity consumption (+1.4\%). They determine up to $95 \%$ of the impacts from the manufacture of glueless diapers. The impacts of all other process equipment make up the remaining $5 \%$. It is notable that the impacts related to material bonding are reduced by $45 \%-86 \%$ compared to the standard gluing process due to the reduced use of electricity in these stages. Moreover, glueless process does not need a pneumatic system to build the absorbent core, bringing additional environmental savings.

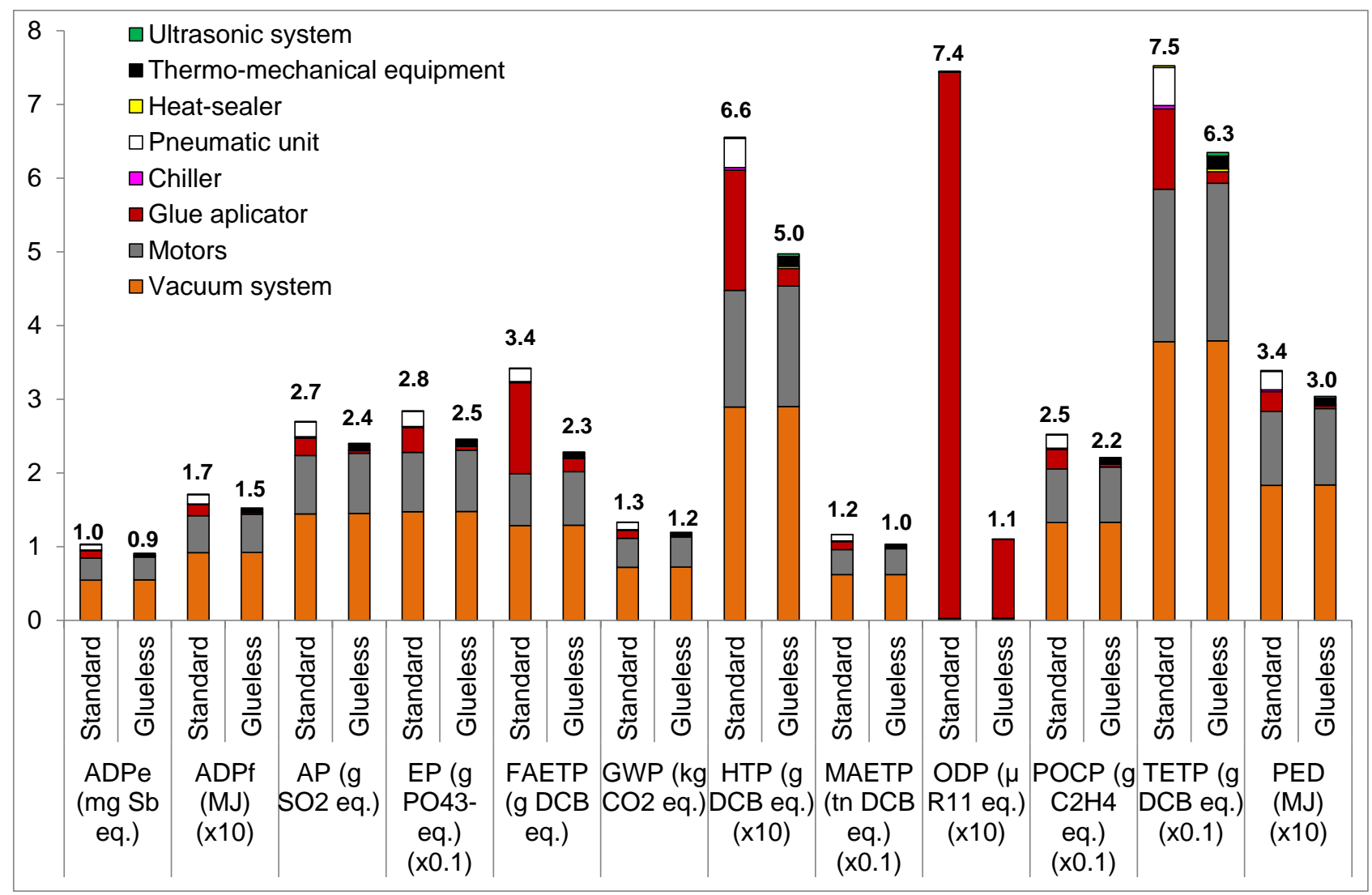

Figure 4 Contribution to the impacts of different manufacturing steps for standard and glueless diapers.

[Impacts expressed per 1,000 diapers. For the impacts nomenclature, see Figure 2.]

\subsection{Environmental impacts of glueless diapers at different production levels}

These annual savings from the manufacture of glueless diapers relative to the standard units are summarised in Table 5 for different production levels. They have been estimated by scaling up the results for the functional unit of 1,000 diapers, discussed in the previous section. As those results refer to the production in Italy, the impacts of the production in the EU have been determined separately, based on the data provided in section 2.2.3. These impacts, also for the functional unit of 1,000 diapers, can be found in Table S7 in the SI; they have been used to estimate the annual impacts at the EU level.

As indicated in Table 5, significant savings can be achieved by replacing standard with glueless diapers. For example, 2,100 t $\mathrm{CO}_{2}$ eq. can be saved annually just by one P10 platform; at the plant level the savings increase to 8,600 t $\mathrm{CO}_{2}$ eq./yr and at the EU level to $184,400 \mathrm{t} \mathrm{CO}_{2}$ eq./yr. The latter is equivalent to avoiding the annual GHG emissions of 92,257 households (EEA, 2014b). The related PED savings range from 0.2 to $15.6 \mathrm{TJ} / \mathrm{yr}$, equivalent to $87 \%$ of the annual electricity 
generation in Italy from biomass (ENTSO-E, 2016). The savings in other environmental impacts would be also significant (Table 5).

Table 5 Annual resource and impacts savings by glueless compared to standard diapers for different production levels.

\begin{tabular}{|c|c|c|c|c|c|c|}
\hline \multirow{2}{*}{$\begin{array}{l}\text { Resources and } \\
\text { impacts }^{a}\end{array}$} & \multirow{2}{*}{$\begin{array}{c}\mathrm{P} 10 \\
\text { production } \\
\text { platform }^{\mathrm{b}}\end{array}$} & \multirow{2}{*}{$\begin{array}{c}\text { Average } \\
\text { industrial }^{\text {plant }}{ }^{\mathrm{C}}\end{array}$} & \multirow[t]{2}{*}{ Italy ${ }^{\mathrm{d}}$} & \multirow[t]{2}{*}{$E U^{e}$} & \multicolumn{2}{|c|}{ Allocation of savings } \\
\hline & & & & & $\mathrm{GMB}^{\dagger}$ & $\mathrm{OAC}^{\dagger}$ \\
\hline Raw materials (kt) & 2.1 & 8.3 & 16.6 & 192.2 & $7.1 \%$ & $92.9 \%$ \\
\hline Electricity (MWh) & 72.5 & 290.2 & 579.6 & 6711.6 & $100.0 \%$ & $0.0 \%$ \\
\hline ADPe (kg Sb eq.) & 1.3 & 5.3 & 10.7 & 123.7 & $40.3 \%$ & $59.7 \%$ \\
\hline ADPf (TJ) & 4.3 & 17.3 & 34.5 & 352.5 & $32.6 \%$ & $67.4 \%$ \\
\hline $\mathrm{AP}\left(\mathrm{t} \mathrm{SO}_{2}\right.$ eq.) & 16.7 & 66.9 & 133.7 & 1552.5 & $9.6 \%$ & $90.4 \%$ \\
\hline $\mathrm{EP}\left(\mathrm{t} \mathrm{PO}{ }^{3-}\right.$ eq. $)$ & 9.2 & 36.9 & 73.8 & 836.7 & $7.5 \%$ & $92.5 \%$ \\
\hline FAETP (kt DCB eq.) & 0.5 & 2.2 & 4.3 & 50.2 & $16.4 \%$ & $83.6 \%$ \\
\hline GWP (kt $\mathrm{CO}_{2}$ eq.) & 2.1 & 8.6 & 17.1 & 184.4 & $28.5 \%$ & $71.5 \%$ \\
\hline HTP (kt DCB eq.) & 1.8 & 7.3 & 14.6 & 165.9 & $49.6 \%$ & $50.4 \%$ \\
\hline MAETP (Mt DCB eq.) & 1.5 & 6.0 & 12.0 & 136.9 & $11.0 \%$ & $89.0 \%$ \\
\hline ODP (kg R11 eq.) & 0.1 & 0.5 & 1.0 & 12.0 & $18.8 \%$ & $81.2 \%$ \\
\hline $\mathrm{POCP}\left(\mathrm{t} \mathrm{C}_{2} \mathrm{H}_{4}\right.$ eq. $)$ & 1.4 & 5.5 & 10.9 & 103.9 & $32.0 \%$ & $68.0 \%$ \\
\hline TETP (t DCB eq.) & 3.4 & 13.7 & 27.3 & 291.0 & $22.8 \%$ & $77.2 \%$ \\
\hline PED (PJ) & 0.2 & 0.7 & 1.4 & 15.6 & $9.3 \%$ & $90.7 \%$ \\
\hline $\begin{array}{l}\text { a For the impacts nom } \\
\text { b } 225 \text { million diapers. } \\
{ }^{\mathrm{c}} 900 \text { million diapers. } \\
900 \text { billion diapers. } \\
{ }^{\mathrm{d}} 1.8 \text { billion diapers. } \\
{ }^{\mathrm{e}} 20.8 \text { bill }\end{array}$ & ature, see $F$ & & & & & \\
\hline
\end{tabular}

Glueless diapers would also reduce the annual consumption of raw materials from 2,100 t (P10 platform) to $192,200 \mathrm{t}(\mathrm{EU})$. At the EU level, this would compensate municipal waste generation by almost 405,000 people (Eurostat, 2016e). The annual electricity savings of $6.7 \mathrm{GWh}$ at the EU level would be equivalent to the electricity consumption by 4.7 million incandescent $60 \mathrm{~W}$ light bulbs used over 24 hours. The alternative bonding in glueless manufacturing would also reduce annual glue consumption by 148 tonnes per production platform up to 13,700 t at the EU level. The latter corresponds to a saving of $56,500 \mathrm{t} \mathrm{CO}_{2}$ eq. and $1.5 \mathrm{PJ}$ primary energy. Thus, these findings demonstrate that a small improvement in the resource efficiency of disposable baby diapers (e.g. a reduction of just $0.63 \mathrm{~g}$ of glue per diaper) can lead to notable annual savings in resources and environmental impacts, given the vast amount of diapers produced and consumed globally.

\subsection{Environmental impacts for different market penetration of glueless diapers}

To streamline the discussion, this section focuses on the savings in GWP and PED as two illustrative examples. These results are given in Figure 5 and Figure 6 which show the GWP and PED savings that can be achieved in the EU through the implementation of glueless innovations over the period 2016-2020. For the savings in the other impacts, see Table S8 in the SI.

As can be seen in the figures, the annual GWP and PED savings in 2020 would range from $10,000-191,000 \mathrm{t} \mathrm{CO}_{2}$ eq. and from 0.8-15.9 PJ by 2020, depending on the market penetration of the glueless technology. Consequently, the cumulative GWP savings over the period 2016-2020 would range from 30,200 t to $566,400 \mathrm{t}$, equivalent to avoiding the annual GHG emissions by 15,100 to 283,330 households in the EU (EEA, 2014). The cumulative savings for PED by 2020 would vary from 2.5 PJ to $47.4 \mathrm{PJ}$, corresponding to the final energy consumption by 43,700 to 819,500 households in the EU (EEA, 2013). Therefore, even assuming very conservative market penetration of glueless (Market A), the GWP and PED savings would be substantial. These findings suggest that replacing standard with glueless diapers can contribute actively to meeting the energy and climate change goals set in the EU 2020 strategy (EC, 2010).

The cumulative raw materials savings would also be significant, ranging from $31,200-584,400 \mathrm{t}$ by 2020. This would avoid the annual generation of municipal waste by 65,600 to $1,230,330$ people 
(Eurostat, 2016e). Consequently, glueless diapers can also contribute notably to the EU resource efficiency goals (EC, 2011).

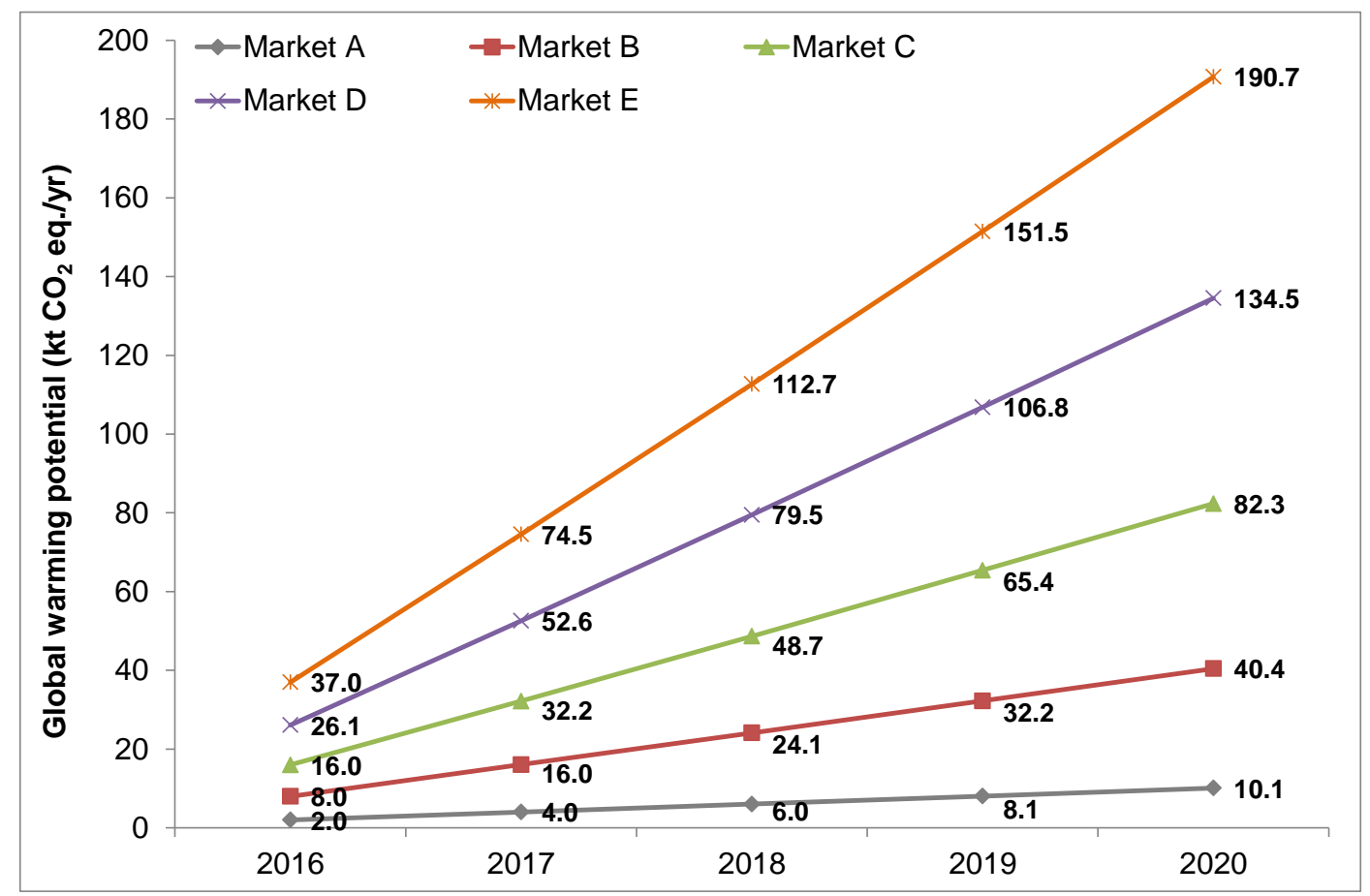

Figure 5 Cumulative annual savings in greenhouse gas emission in the EU for different market penetration of glueless diapers.

[Market A: poor uptake (5.3\% by 2020$)$; Market B: low uptake (21.2\%), Market C: moderate uptake (43.2\%), Market D: high uptake (70.2\%), Market E: very high uptake (100\%). For further details, see Table 4.]

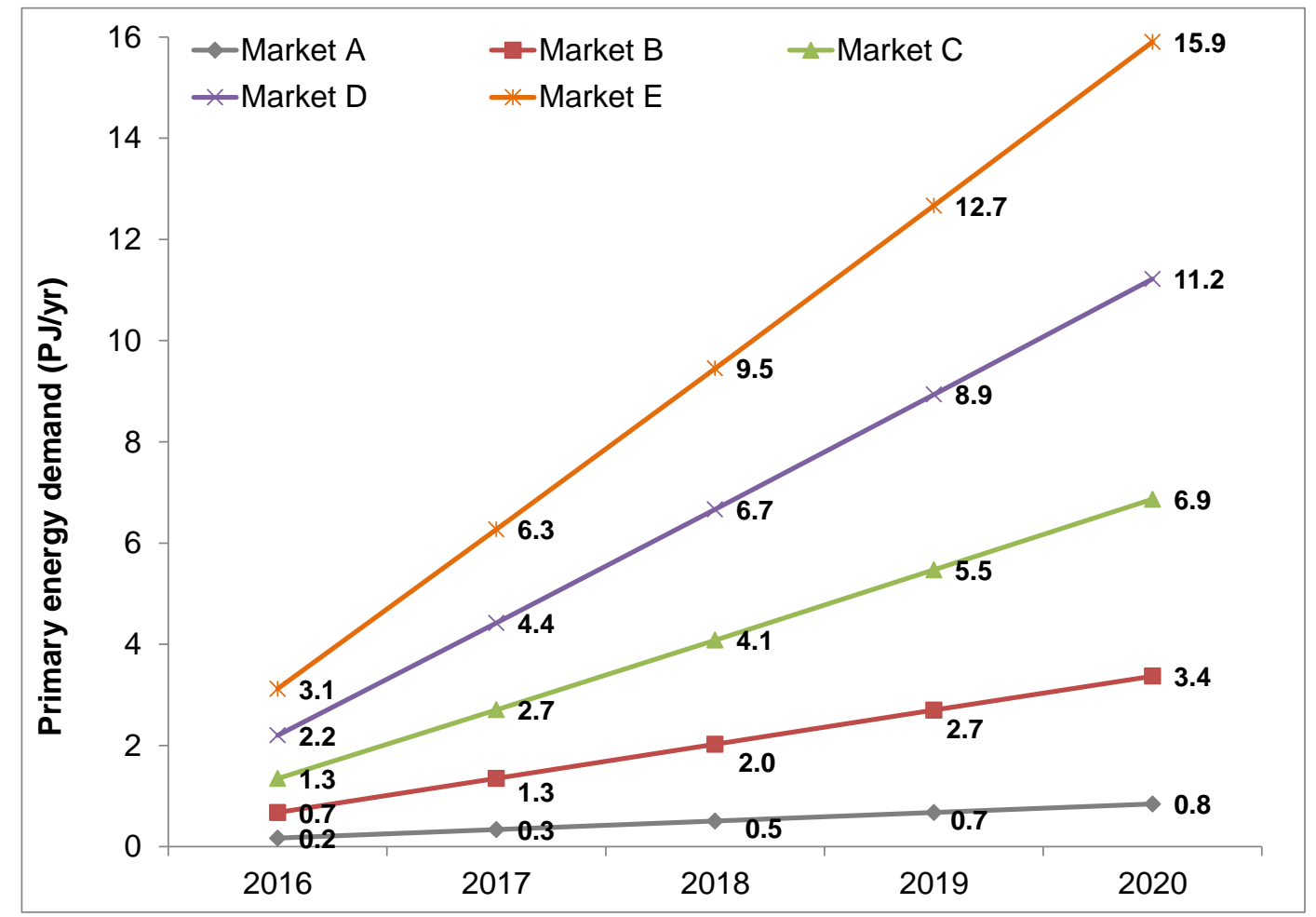

Figure 6 Cumulative annual savings in primary energy demand in the EU for different market penetration of glueless diapers.

[Market A: poor uptake (5.3\% by 2020$)$, Market B: low uptake $(21.2 \%)$, Market C: moderate uptake (43.2\%), Market D: high uptake (70.2\%), Market E: very high uptake (100\%) For further details, see Table 4.] 


\subsection{Comparison of results with literature}

As there are no other LCA studies of the diaper innovations considered here, comparison of the results is only possible for the standard product. This is shown in Figure 7 which compares the impacts estimated in this study with those reported by Cordella et al. (2015) who have used the same impact assessment method (CML) and software (Gabi) as in this paper. Likewise, the data provided by Cordella et al. (2015) are assumed to be representative of the average products available on the European market (although their results refer to year 2011). Only the GWP and PED are considered as illustrative examples.

As can be seen in Figure 7, the values obtained in this study are 30\%-40\%lower than those reported by Cordella et al. This difference is due to the differing weight and composition of the diapers considered in the two studies, the manufacturing steps analysed and the assumptions for transport and waste management. Thus, considering all these differences, the results are in relatively good agreement.

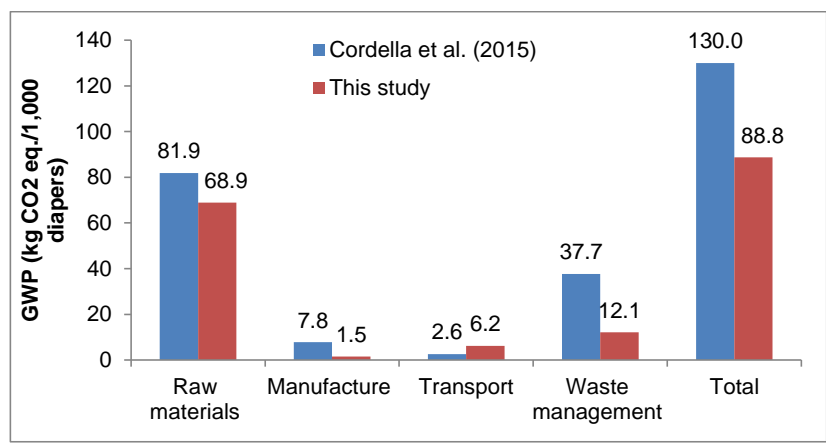

a) Global warming potential

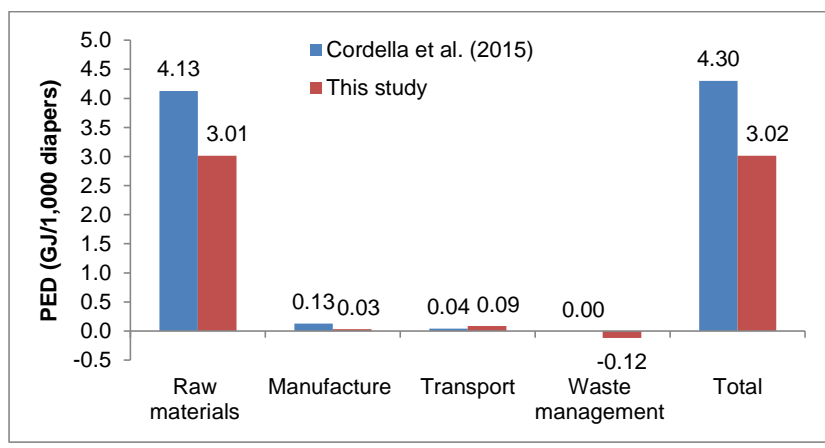

b) Primary energy demand

Figure 7 Comparison of results with literature for standard diapers

[Functional unit: 1,000 diapers].

\subsection{Sensitivity analysis}

This section considers the effect of reducing the impacts of key raw materials by $15 \%$, based on the historical improvements in the environmental performance of disposable baby diapers (see section 2.2.5). The analysis is first carried out for the functional unit of 1,000 diapers, followed by the production at the EU level for different market penetrations. In both cases, the production is assumed in the EU and the impacts refer to the year 2020. Again, the analysis here is limited to GWP and PED for brevity. A general trend in the other impacts would be similar.

The results in Table 6 show that reducing the impacts of the raw materials by $15 \%$ would reduce the GWP and PED of the standard and glueless diapers by $12 \%$ and $15 \%$, respectively. This would in turn reduce the GWP savings from the glueless relative to the standard product by $5.8 \%$ (from $9.0 \mathrm{~kg} \mathrm{CO}$ eq. $/ 1,000$ diapers (Table S7) to $8.5 \mathrm{~kg} \mathrm{CO}_{2}$ eq.). The PED savings would drop by $14.8 \%$.

Considering the production at the EU level and different market penetration, the cumulative GWP savings would range from 29,000 t up to $542,000 \mathrm{t} \mathrm{CO}_{2}$ eq., whereas PED savings would amount to 2.3-42.2 PJ (Figure 8). Consequently, glueless diapers would contribute to notable environmental savings even if the raw materials with the improved environmental performance were also used for the standard diapers. All these findings further demonstrate the environmental relevance of the greater resource efficiency of the glueless diapers. Therefore, improving resource efficiency in diaper manufacturing is a key strategy to keep enhancing the environmental sustainability of these products until more radical sustainable innovations can be implemented by the industry. 
Table 6 The effect of reducing the impacts of key raw materials on the total GWP and PED of standard and glueless diapers produced in the EU in 2020 (functional unit: 1,000 diapers).

\begin{tabular}{|c|c|c|c|c|c|}
\hline \multirow[t]{2}{*}{ Raw materials } & \multirow[t]{2}{*}{$\begin{array}{l}\text { Environmental } \\
\text { impacts }\end{array}$} & \multicolumn{2}{|c|}{ Baseline } & \multicolumn{2}{|c|}{$\begin{array}{l}15 \% \text { reduction in impacts of } \\
\text { materials by } 2020\end{array}$} \\
\hline & & Standard & Glueless & Standard & Glueless \\
\hline \multirow[t]{2}{*}{ Fluff pulp (kg) } & GWP (kg CO${ }_{2}$ eq. $)$ & 6.6 & 1.58 & 5.6 & 1.34 \\
\hline & PED (MJ) & 1,043 & 248.8 & 886.8 & 211.5 \\
\hline \multirow[t]{2}{*}{$\operatorname{SAP}^{\mathrm{a}}(\mathrm{kg})$} & GWP (kg CO ${ }_{2}$ eq.) & 32.1 & 29.9 & 27.3 & 25.4 \\
\hline & PED (MJ) & 965.7 & 901.3 & 820.9 & 766.1 \\
\hline \multirow[t]{2}{*}{ Nonwovens (kg) } & GWP (kg CO $\mathrm{CO}_{2}$ eq. & 21.2 & 27.2 & 18.0 & 23.1 \\
\hline & PED (MJ) & 736.2 & 922.1 & 625.7 & 783.8 \\
\hline \multirow[t]{2}{*}{ LDPE $^{\mathrm{b}}$ film (kg) } & GWP (kg CO $\mathrm{CO}_{2}$ eq. & 2.5 & & 2.15 & 2.15 \\
\hline & PED (MJ) & 2.53 & 2.53 & 72.2 & 72.2 \\
\hline \multirow[t]{2}{*}{ Elastics (kg) } & GWP (kg CO 2 eq.) & 63.0 & 63.0 & 2.15 & 2.15 \\
\hline & PED (MJ) & 3.4 & 3.4 & 53.6 & 53.6 \\
\hline \multirow[t]{2}{*}{ Adhesive (kg) } & GWP (kg CO 2 eq.) & 3.4 & 1.2 & 2.9 & 1.0 \\
\hline & PED (MJ) & 99.1 & 33.7 & 84.2 & 28.7 \\
\hline \multirow[t]{2}{*}{ Packaging (kg) } & GWP (kg CO $\mathrm{CO}_{2}$ eq.) & 0.57 & 0.55 & 0.49 & 0.49 \\
\hline & PED (MJ) & 21.4 & 20.1 & 18.2 & 17.1 \\
\hline \multirow[t]{2}{*}{ Total diapers } & GWP (kg CO Cq. eq & 89.0 & 80.0 & 78.7 & 70.2 \\
\hline & PED (MJ) & 3,014 & 2,265 & 2,562 & 1,924 \\
\hline
\end{tabular}

${ }^{a}$ SAP: superabsorbent polymer.

${ }^{\mathrm{b}}$ LDPE: low density polyethylene.

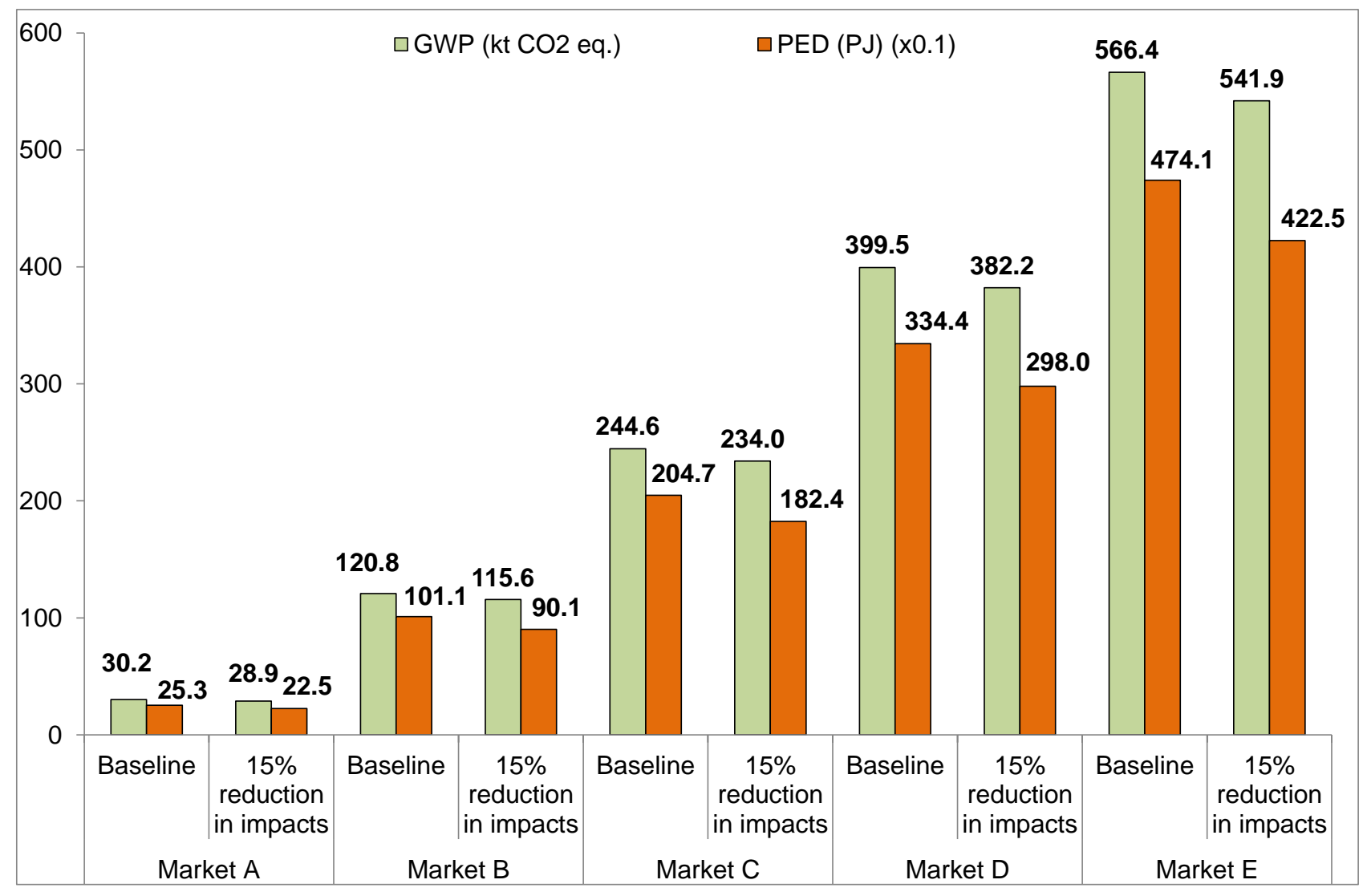

Figure 8 The effect on the total GWP and PED of reducing the impacts of key raw materials used for the production of standard and glueless diapers at the EU level in 2020.

[Market A: poor uptake of glueless diapers $(5.3 \%$ by 2020$)$, Market B: low uptake $(21.2 \%)$, Market C: moderate uptake $(43.2 \%)$, Market D: high uptake $(70.2 \%)$, Market E: very high uptake $(100 \%)$. For the amount of diapers produced in each scenario, see Table 4.] 


\section{Conclusions}

This paper has considered the potential improvements in the resource efficiency and environmental performance of disposable baby diapers through innovations in product design (material optimisation) and the manufacturing process (implementation of cleaner bonding technologies). The results show that these innovations lead to $23 \%$ lower material requirements (9.2 kg/1,000 diapers) and $10 \%$ lower energy consumption (1.2 MJ/1,000 diapers) in the manufacture compared to the standard process. Lower raw material inputs also reduce transport and waste management requirements. Consequently, glueless diapers have more than $50 \%$ lower eutrophication, freshwater and marine water ecotoxicity, human toxicity and ozone depletion than the standard product. Global warming potential is reduced by $10 \%$ and primary energy by $25 \%$. For different levels of market penetration, the annual savings at the EU level range from 2000-191,000

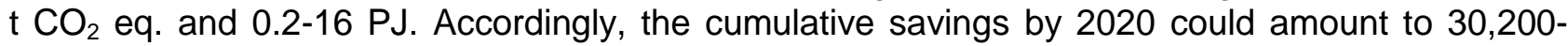
$566,400 \mathrm{t} \mathrm{CO}_{2}$ eq. and 2.5-47.4 PJ. Glueless diaper manufacturing could also reduce annual material requirements by $2100-196,100 \mathrm{t}$, resulting in the cumulative savings of $31,200-584,400 \mathrm{t}$ by 2020 .

These findings demonstrate that given the increasing demand for disposable baby diapers, already exceeding 20 billion units per year in the EU, even small improvements in the resource efficiency can lead to significant environmental savings globally. Glueless bonding technologies could also be applied in the manufacture of other absorbent hygiene products, such as feminine hygiene and adult incontinence products. Additionally, these glueless technological innovations could stimulate implementation in other industries, such as packaging, textile and furniture. This would help towards meeting the energy, climate and resource efficiency goals of the EU 2020 strategy.

However, further research and innovations are required to improve the resource efficiency and environmental performance of disposable baby diapers. The vacuum systems and the motors are the most energy intensive equipment used in glueless diaper manufacturing. Consequently, improvement in their energy efficiency would bring additional resource and environmental savings. Likewise, the use of glue is still inevitable in diaper manufacturing. Further re-engineering and technology optimisation should concentrate on complete elimination of glue bonding systems from manufacturing. However, one of the most important strategies for improving the environmental performance of diapers is further reduction in the environmental impacts of raw materials, including the use of alternatives. It is also important to develop effective post-consumer waste recycling and composting schemes to reduce resource use and waste generation.

Additionally, studies focused on sustainable business model innovation through the consideration of circular economy principles can help decouple industrial production and economic performance from resource consumption and environmental impacts. In this process, collaboration between nonwoven producers, diaper manufacturers, consumers and other relevant stakeholders in the entire supply chain is essential. In the meantime, making life cycle inventory data of nonwoven and diaper products publicly-available would help LCA practitioners, including eco-designers and industrial ecologists, to continue improving environmental performance of diapers and the absorbent hygiene industry as a whole.

\section{Acknowledgements}

The authors would like to thank the European Commission for the financial support received through the LIFE12 ENV/IT/000423 project entitled "Petrol based glue and energy consumption reduction in diapers production processes". JMFM, SAP and AA would like also to acknowledge the whole team at Fameccanica.Data SpA for their collaboration and technical support during the project.

\section{References}

Arena, U., Ardolino, F., Di Gregorio, F., 2016. Technological, environmental and social aspects of a recycling process of post-consumer absorbent hygiene products. J. Clean. Prod. 127, 289-301. https://doi.org/10.1016/j.jclepro.2016.03.164. 
Clancy, G., Fröling, M., Svanström, M., 2013. Changing from petroleum to wood-based materials: critical review of how product sustainability characteristics can be assessed and compared. J. Clean. Prod. 39, 372-385. https://doi.org/10.1016/j.jclepro.2012.07.027.

Colon, J., Ruggieri, L., Sanchez, A., Gonzalez, A., Puig, I., 2010. Possibilities of composting disposable diapers with municipal solid wastes. Waste Manage. Res. 29(3), 249-259. https://doi.org/10.1177/0734242X10364684.

Cordella, M., Bauer, I., Lehmann, A., Schulz, M., Wolf, O., 2015. Evolution of disposable baby diapers in Europe: life cycle assessment of environmental impacts and identification of key areas of improvement. J. Clean. Prod. 95, 322-331. https://doi.org/10.1016/j.jclepro.2015.02.04.

EDANA, 2005. Sustainability report: baby diapers and incontinence products. European Disposables and Nonwovens Association (EDANA), Brussels.

EDANA, 2008. Sustainability report 2007-2008: absorbent hygiene products. European Disposables and Nonwovens Association (EDANA), Brussels.

EDANA, 2011. Sustainability report 2011. European Disposables and Nonwovens Association (EDANA), Brussels.

EDANA, 2015. Sustainability report. European Disposables and Nonwovens Association (EDANA), Brussels.

EEA, 2013. Final energy consumption by sector and fuel. Indicator assessment. Data and maps. European Environment Agency (EEA), Brussels.

EEA, 2014. Annual European Union greenhouse gas inventory 1990-2012 and inventory report 2014. Submission to the UNFCCC Secretariat. Technical report No 09/2014. European Environment Agency (EEA), Brussels.

ENTSO-E, 2015. Scenario outlook and adequacy forecast (SO\&AF) 2014-2030 dataset, European Network of Transmission System Operators for Electricity (ENTSO-E), Brussels.

ENTSO-E, 2016. ENTSO-E yearly statistics \& adequacy retrospect 2014. European Network of Transmission System Operators for Electricity (ENTSO-E), Brussels.

Environment Agency, 2008. An updated life cycle assessment study for disposable and reusable nappies. Science report: SC010018/SR2. Environmental Agency, Bristol.

Espinosa-Valdemara, R.M., Sotelo-Navarro, P.X., Quecholac-Pina, X. García-Rivera, M.A., Beltrán-Villavicencio, M., Ojeda-Benítez, S., Vázquez-Morillas, A., 2014. Biological recycling of used baby diapers in a small-scale composting system. Res. Cons. Recycl. 87, 153-157. https://doi.org/10.1016/j.resconrec.2014.03.015.

Euromonitor International, 2015. Tissue and Hygiene: Euromonitor from trade sources/national statistics, London.

EC, 2010. EUROPE 2020 a strategy for smart, sustainable and inclusive growth. Communication of European Commission (COM (2010) 2020 Final), Brussels.

EC, 2011. A resource-efficient Europe: flagship initiative under the Europe 2020 strategy. Communication from the Commission to the European Parliament, the Council, the European Economic and Social Committee and the Committee of the Regions. COM(2011) 21, Brussels.

Eurostat, 2016a. Greenhouse gas emissions statistics. http://ec.europa.eu/eurostat/statisticsexplained/index.php/Greenhouse gas emission statistics (accessed September 2016).

Eurostat, 2016b. Consumption of energy. http://ec.europa.eu/eurostat/statisticsexplained/index.php/Consumption of energy (accessed September 2016).

Eurostat, 2016c. EUROSTAT waste statistics. Waste generation and treatment. http://ec.europa.eu/eurostat/web/environment/waste/database (accessed March 2016).

Eurostat, 2016d. EUROSTAT electricity and heat statistics. Supply, transformation and consumption of heat. Annual data. http://ec.europa.eu/eurostat/web/energy/data/database (accessed April 2016).

Eurostat, 2016e. Municipal waste statistics. http://ec.europa.eu/eurostat/statisticsexplained/index.php/Municipal_waste_statistics (accessed September 2016).

Famecanica, 2016. FA-X P10: Fameccanica high capacity machine for the manufacturing of baby diapers. http://www.fameccanica.com/en/products-solutions/baby/premium/fa-x-p10 (accessed March 2016).

FEFCO and Cepi, 2012. Life cycle studies 2012. European Database for Corrugated Board, Brussels.

Gontia, 2014. Life cycle assessment of bio-based sodium poly-acrylate production from pulp mill side streams-Case at a TMP and sulphite pulp mill. Master's Thesis. Department of Energy and 
Environment, Division of Environmental System Analysis, Chalmers University of Technology, Gothenburg, (Sweden).

Guinee, J.B., Gorree, M., Heijungs, R., Huppes, G., Kleijn, R., Koning, A. de, Oers, L. van,Wegener Sleeswijk, A., Suh, S., Udo de Haes, H.A., Bruijn, H. de, Duin, R. van, Huijbregts, M.A.J., 2002. Handbook on life cycle assessment. Operational guide to the ISO standards. I: LCA in Perspective. Ila: Guide. Ilb: Operational annex. III: Scientific background. Kluwer Academic Publishers, Dordrecht (the Netherlands).

ISO, 2006a. ISO 14040. Environmental management. Life cycle assessment. Principles and framework. International Organization for Standardization (ISO), Geneva.

ISO, 2006b. ISO 14044. Environmental management. Life cycle assessment. Requirements and guidelines. International Organization for Standardization (ISO), Geneva.

JRC, 2013. Development of EU ecolabel criteria for absorbent hygiene products. Preliminary report. Draft v.5. Joint Research Centre (JRC-IPTS), DEKRA Consulting GmbH - Sustainability Solutions and PE International.

Mirabella N, Castellani V, Sala S (2013) Life cycle assessment of bio-based products: a disposable diaper case study. Int. J. Life Cycle Assess. 18, 1036-1047. DOI 10.1007/s11367-013-0556-6.

Nonwoven Industry, 2016. A baby diaper for the modern parent. https://www.nonwovensindustry.com/contents/view online-exclusives/2016-04-26/a-baby-diaper-for-the-modern-parent/ (accessed April 2016).

SCLCI, 2010. Ecoinvent v.2.2 database. Swiss Centre for Life Cycle Inventories (SCLCI), Dübendorf.

Schmidt, 2012. Plastberegner.dk-LCA tool for plastics converters in Denmark. Documentation of the tool and database. 2.-0 LCA Consultants, Aalborg.

Thinkstep, 2016. GaBi 7 software system and databases for life cycle engineering. Stuttgart.

Weisbrod, A.V., Van Hoof, G., 2012. LCA-measured environmental improvements in Pampers ${ }^{\circledR}$ diapers. Int. J. Life Cycle Assess. 17, 145-153. DOI 10.1007/s11367-011-0343-1. 


\section{Improving resource efficiency and environmental impacts through novel design and manufacturing of disposable baby diapers}

Joan Manuel F. Mendoza, Simona Andreea Popa, Francesco D'Aponte, Diego Gualtieri and Adisa Azapagic

\section{SUPPORTING INFORMATION}

Table S1 Material requirements for manufacture of standard and glueless diapers ( $\mathrm{g} / 1,000$ diapers).

\begin{tabular}{|c|c|c|c|}
\hline Unit processes & Materials & Standard & Glueless \\
\hline \multirow[t]{5}{*}{ Elastics entrapment by cuffs } & Glue & 40.4 & - \\
\hline & Lubricants & 0.07 & 0.04 \\
\hline & Solvents & 0.60 & - \\
\hline & Cardboard box & 4.8 & 3.6 \\
\hline & Plastic film & 7.9 & 7.7 \\
\hline \multirow{5}{*}{$\begin{array}{l}\text { Application of acquisition and distribution layer on the } \\
\text { topsheet }\end{array}$} & Glue & 80.8 & - \\
\hline & Lubricants & 0.26 & 0.19 \\
\hline & Solvents & 0.72 & - \\
\hline & Cardboard box & 20.7 & 18.3 \\
\hline & Plastic film & 46.1 & 45.7 \\
\hline \multirow[t]{5}{*}{ Absorbent core building } & Glue & 373.7 & - \\
\hline & Lubricants & 2.54 & 2.05 \\
\hline & Solvents & 2.14 & - \\
\hline & Cardboard box & 29.7 & 6.8 \\
\hline & Plastic film & 97.3 & 93.0 \\
\hline \multirow[t]{5}{*}{ Frontal tape attachment on backsheet } & Glue & 202.0 & 131.3 \\
\hline & Lubricants & 0.37 & 0.48 \\
\hline & Solvents & 0.98 & 0.74 \\
\hline & Cardboard box & 15.3 & 13.2 \\
\hline & Plastic film & 26.5 & 26.2 \\
\hline \multirow[t]{5}{*}{ Ears reinforcement and application on backsheet } & Glue & 252.5 & 191.9 \\
\hline & Lubricants & 0.07 & 0.04 \\
\hline & Solvents & 0.65 & - \\
\hline & Cardboard box & 15.0 & 13.2 \\
\hline & Plastic film & 24.1 & 23.7 \\
\hline
\end{tabular}

Table S2 Consumption of electricity (high voltage) in manufacture of standard and glueless diapers ( $\mathrm{kJ} / 1,000$ diapers)

\begin{tabular}{llrr}
\hline Unit processes & Equipment & Standard & Glueless \\
\hline Elastics entrapment by cuffs & Motors & 67.2 & 91.2 \\
& Glue system & 102.0 & - \\
& Chiller unit & 41.4 & - \\
Application of acquisition and distribution layer on the & Heat-sealer & 38.4 & 38.4 \\
topsheet & Motors & 226.3 & 202.1 \\
& Vacuum system & 558.2 & 443.4 \\
& Glue system & 121.4 & - \\
& Chiller unit & 37.4 & - \\
Absorbent core building & Ultrasonic equipment & - & 36.0 \\
& Motors & 2833 & 2914 \\
& Vacuum system & 5167 & 4963 \\
& Glue system & 360.6 & - \\
Frontal tape attachment on backsheet & Pneumatic system & 900.0 & - \\
& Thermo-mechanical unit & & - \\
& Motors & 334.8 & 375.6 \\
Ears reinforcement and application on backsheet & Vacuum system & 850.2 & 1187 \\
& Glue system & 165.6 & 124.2 \\
& Ultrasonic equipment & - & 48.0 \\
& Motors & 135.6 & 135.6 \\
& Glue system & 110.4 & - \\
& Heat-sealer & - & 27.6 \\
\hline
\end{tabular}


Table S3 Italian and EU heat generation mix with corresponding primary energy demand (PED) and global warming potential (GWP) ${ }^{\mathrm{a}}$.

\begin{tabular}{lrr}
\hline Heat source & Italy (\%) & EU (\%) \\
\hline Natural gas & 74.00 & 61.64 \\
Hard coal & 0.92 & 20.24 \\
Heavy fuel oil & 3.95 & 1.83 \\
Light fuel oil & 0.30 & 0.32 \\
Biogas & 5.98 & 1.31 \\
Biomass & 14.85 & 14.66 \\
\hline GWP (kg CO 2 eq./MJ) & 0.07 & 0.07 \\
PED (MJ/MJ) & 0.01 & 1.18 \\
\hline${ }^{a}$ Calculated from Eurostat (2016) & &
\end{tabular}

Table S4 Italian and EU electricity mix in 2016 and 2020 with corresponding primary energy demand (PED) and global warming potential (GWP) ${ }^{\text {. }}$.

\begin{tabular}{lccc}
\hline Electricity source & Italy 2016 (\%) & EU 2016 (\%) & EU 2020 (\%) \\
\hline Nuclear & 0.00 & 28.04 & 12.26 \\
Lignite & 0.00 & 10.09 & 4.79 \\
Coal & 13.20 & 14.61 & 8.43 \\
Gas & 34.95 & 12.39 & 22.33 \\
Oil & 6.50 & 1.23 & 0.96 \\
Mixed fuels & 4.25 & 1.27 & 0.89 \\
Other fossil fuels & 1.05 & 3.59 & 0.00 \\
Wind & 5.64 & 8.26 & 19.95 \\
Solar & 8.73 & 3.07 & 11.36 \\
Biomass & 1.86 & 3.53 & 3.16 \\
Geothermal & 1.62 & 0.00 & 0.00 \\
Biogas & 0.46 & 0.47 & 0.00 \\
Renewable hydro & 20.60 & 12.20 & 11.55 \\
Other hydro & 1.14 & 1.26 & 4.32 \\
\hline GWP (kg CO 2 eq./kWh) & 0.39 & 0.44 & 0.31 \\
PED (MJ/kWh) & 10.0 & 9.9 & 10.4 \\
\hline
\end{tabular}

${ }^{\mathrm{a}}$ Calculated from ENTSOE $(2015,2016)$.

Table S5 Contribution of different EU countries to the annual production of disposable baby diapers ${ }^{\mathrm{a}}$.

\begin{tabular}{lcc}
\hline Country & $\mathbf{2 0 1 6 ( \% ) ^ { \mathrm { a } }}$ & $\mathbf{2 0 2 0}(\%)^{\mathbf{b}}$ \\
\hline Austria & 1.7 & 1.7 \\
Belgium & 3.1 & 3.1 \\
Bulgaria & 0.3 & 0.3 \\
Croatia & 1.0 & 1.0 \\
Czech Republic & 1.9 \\
Denmark & 1.0 & 1.3 \\
Estonia & 0.3 & 0.3 \\
Finland & 1.4 & 1.4 \\
France & 13.7 & 14.0 \\
Germany & 14.0 & 13.9 \\
Greece & 1.9 & 1.8 \\
Hungary & 1.5 & 1.6 \\
Ireland & 1.6 & 1.6 \\
Italy & 8.6 & 8.7 \\
Latvia & 0.4 & 0.4 \\
Lithuania & 0.6 & 0.6 \\
Netherlands & 3.9 & 3.8 \\
Poland & 8.9 & 9.4 \\
Portugal & 1.9 & 1.6 \\
Romania & 2.6 & 2.8 \\
Slovakia & 1.1 & 1.1 \\
Slovenia & 0.3 & 0.3 \\
Spain & 9.0 & 7.9 \\
Sweden & 2.9 & 3.0 \\
United Kingdom & 16.0 & 16.7 \\
\hline a Based on total EU production of 20,817.5 billion diapers (Euromonitor International 2015). \\
b Based on total EU production of 21,235.9 billion (own calculation based on Euromonitor International (2015)). \\
\end{tabular}


Table S6 Environmental impacts of 1,000 standard and glueless diapers (production in Italy)

\begin{tabular}{|c|c|c|c|}
\hline Impacts $^{\mathrm{a}}$ & Standard & Glueless & $\begin{array}{c}\text { Savings from } \\
\text { glueless diapers (\%) }\end{array}$ \\
\hline $\mathrm{ADP}_{\mathrm{e}}$ (mg Sb eq.) & -7.3 & -5.9 & \\
\hline $\mathrm{ADP}_{\mathrm{f}}(\mathrm{GJ})$ & 1.8 & 1.7 & 1.1 \\
\hline $\mathrm{AP}\left(\mathrm{g} \mathrm{SO}_{2}\right.$ eq.) & 292.3 & 217.9 & 25.4 \\
\hline $\mathrm{EP}\left(\mathrm{g} \mathrm{PO}_{4}{ }^{3-}\right.$ eq.) & 91.1 & 50.0 & 45.1 \\
\hline FAETP (kg eq.) & 3.9 & 1.5 & 62.1 \\
\hline GWP (kg CO ${ }_{2}$ eq.) & 91.5 & 82.0 & 10.4 \\
\hline HTP (kg DBC eq.) & 13.9 & 5.8 & 58.3 \\
\hline MAETP (t DCB eq.) & 14.4 & 7.8 & 46.1 \\
\hline ODP ( $\mu$ R 11 eq. $)$ & 854.5 & 282.9 & 66.9 \\
\hline POCP ( $\mathrm{g} \mathrm{C}_{2} \mathrm{H}_{4}$ eq. $)$ & 37.7 & 31.7 & 16.1 \\
\hline TETP (g DCB eq.) & 246.8 & 231.6 & 6.2 \\
\hline PED (GJ) & 3.0 & 2.3 & 24.8 \\
\hline
\end{tabular}

${ }^{a}$ ADP $_{\mathrm{e}}$ : Abiotic depletion potential of elements; $\mathrm{ADP}_{\mathrm{f}}$ : Abiotic depletion potential of fossil fuels; AP: Acidification potential; EP: Eutrophication potential; FAETP: Freshwater aquatic ecotoxicity potential; GWP: Global warming potential; HTP: Human toxicity potential; MAETP: Marine aquatic ecotoxicity potential; ODP: Ozone layer depletion potential; POCP: Photochemical oxidants creation potential; TETP: Terrestrial ecotoxicity potential; PED: Primary energy demand.

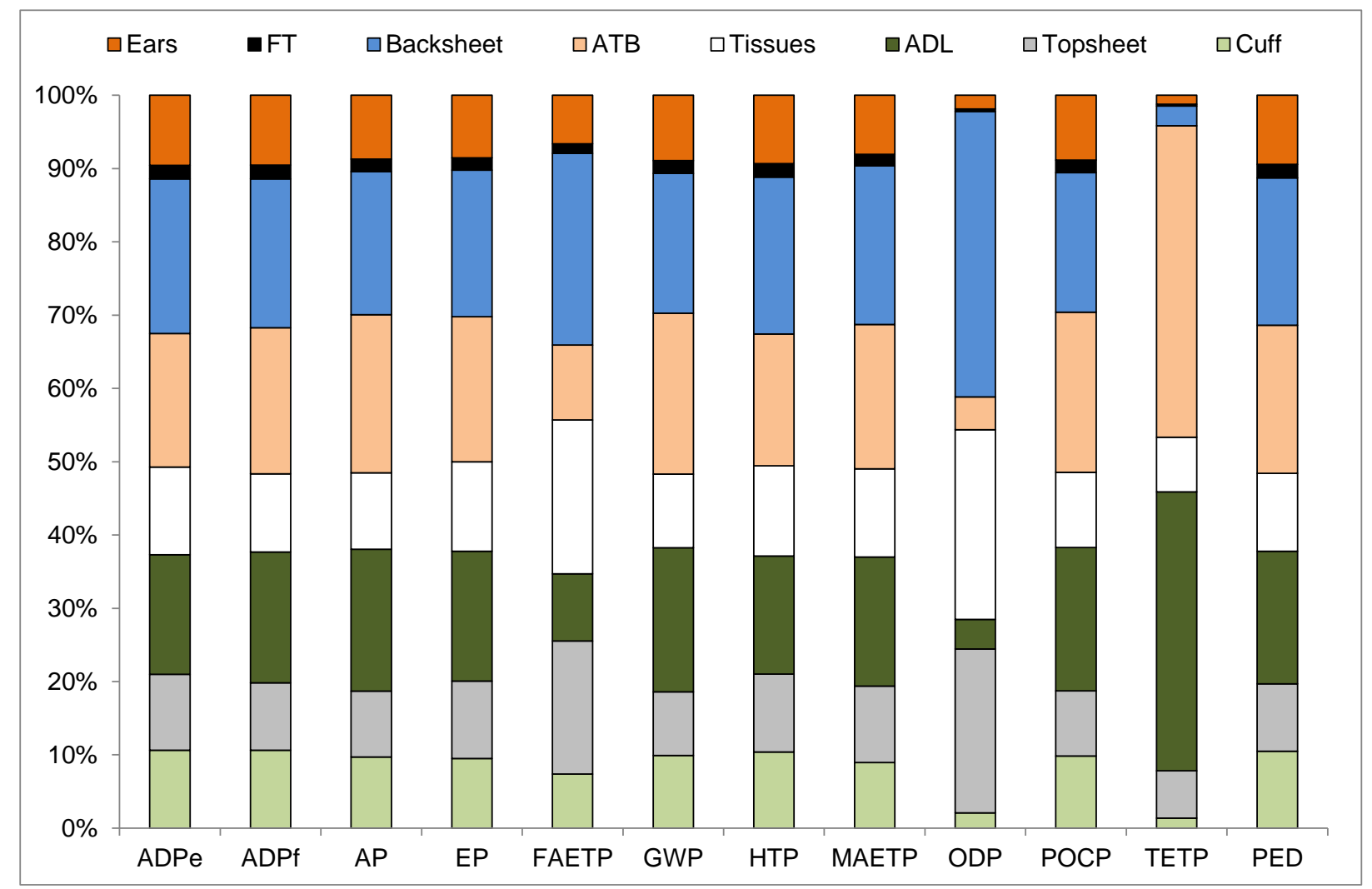

Figure S1 Contribution of nonwoven layers to environmental impacts

[FT: Frontal tape; ATB: Air-through bonded layer; ADL: Acquisition and distribution layer. For the impacts nomenclature, see the footnote to Table S6.] 


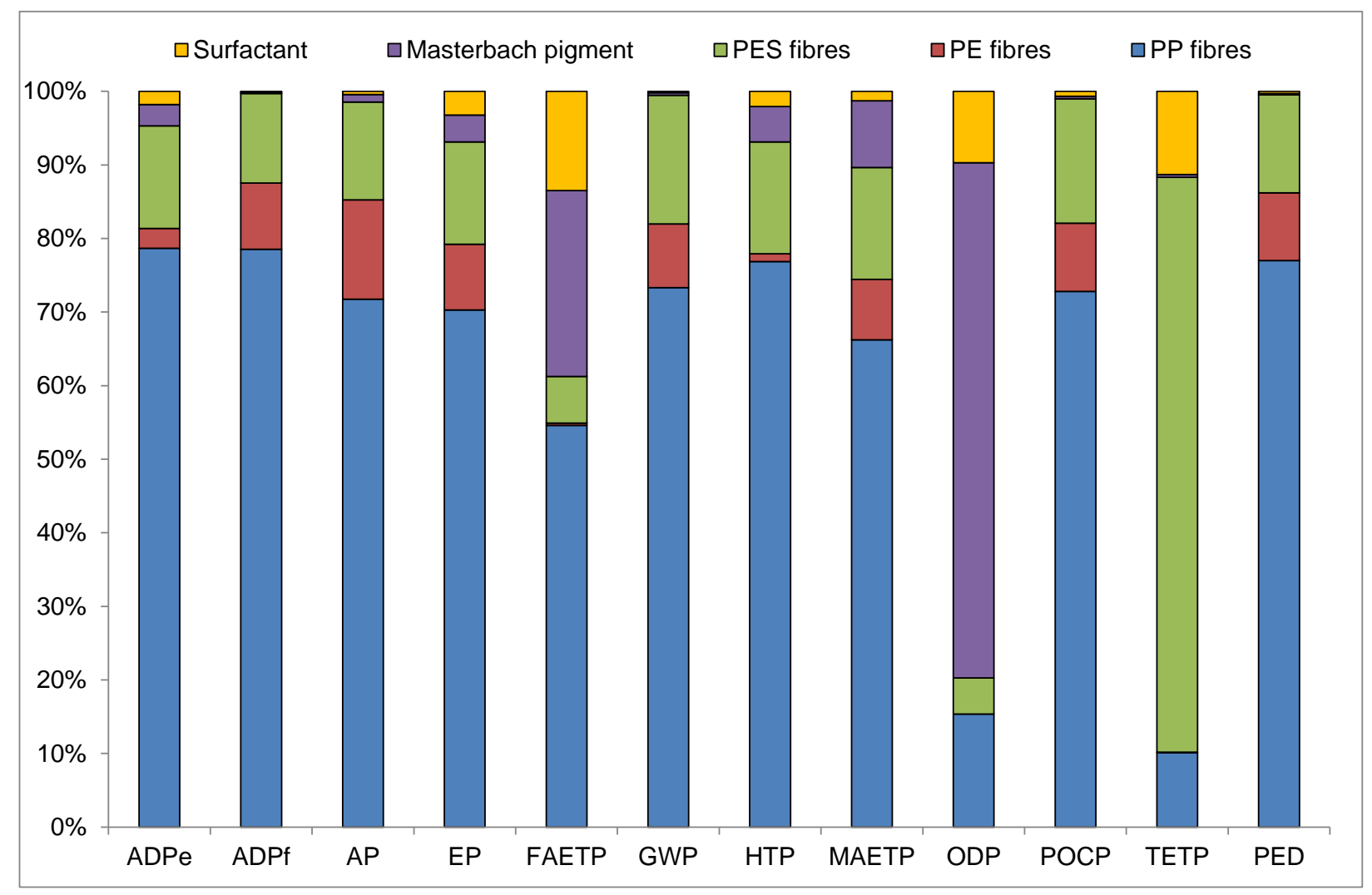

Figure S2 Contribution of nonwoven materials to environmental impacts [For the impacts nomenclature, see the footnote to Table S6.]

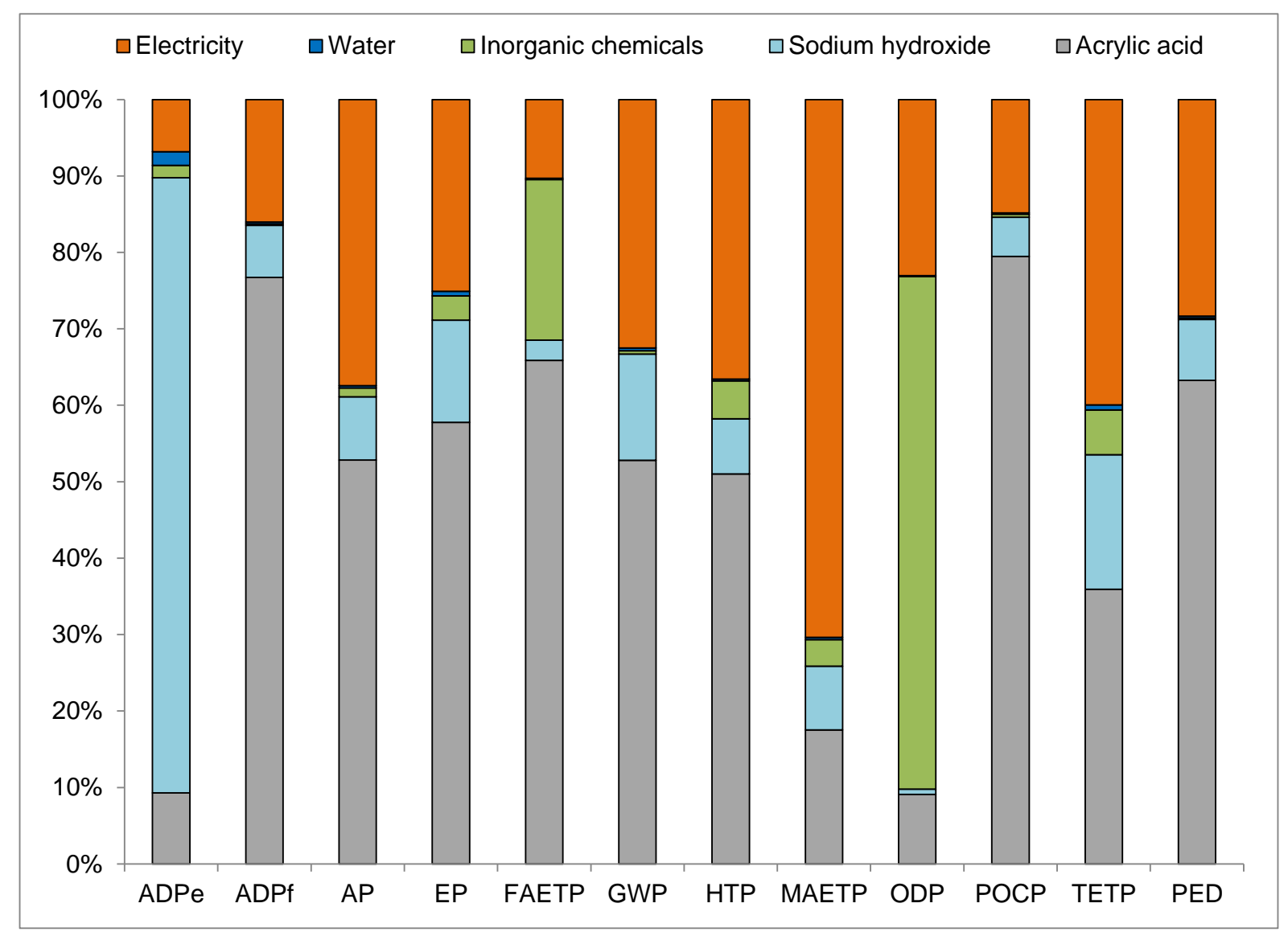

Figure S3 Contribution to environmental impacts of superabsorbent polymer processing [For the impacts nomenclature, see the footnote to Table S6.] 


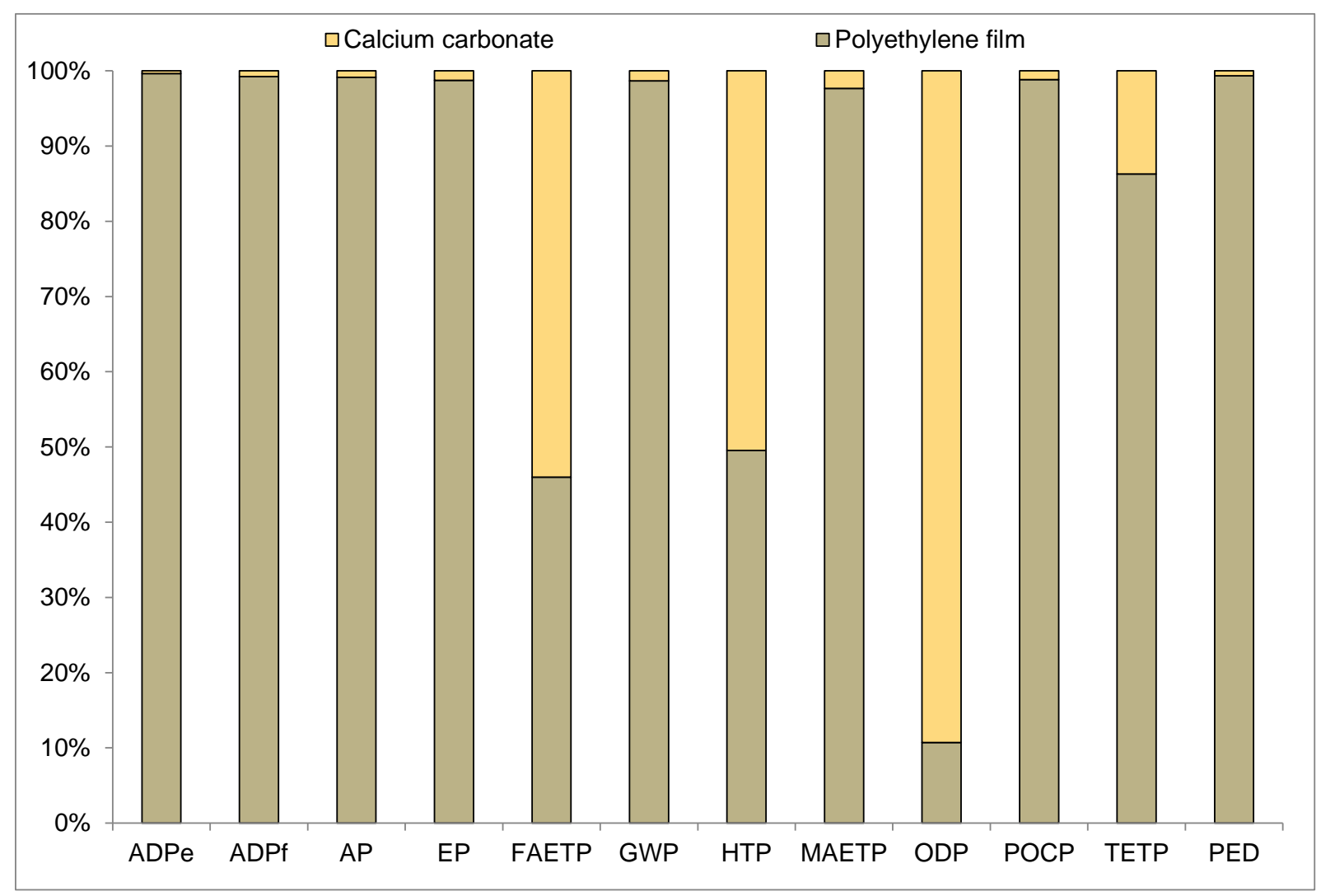

Figure S4 Contribution to environmental impacts of polymer backsheet materials

[For the impacts nomenclature, see the footnote to Table S6.]

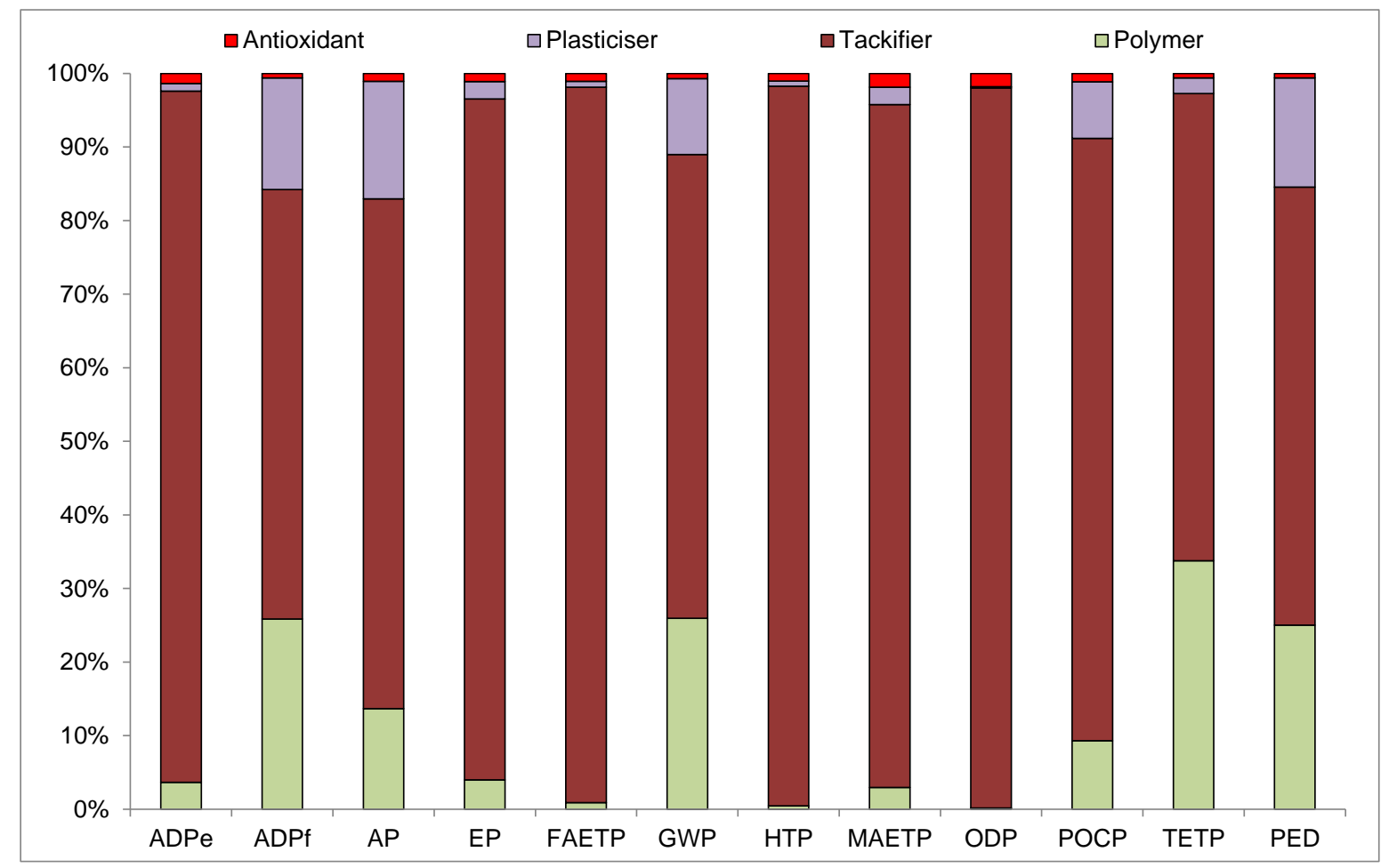

Figure S5 Contribution of glue constituents to environmental impacts

[Tackifier: chemical used in formulating adhesives to increase the tack (stickiness) of the surface of the adhesive. For the impacts nomenclature, see the footnote to Table S6.] 


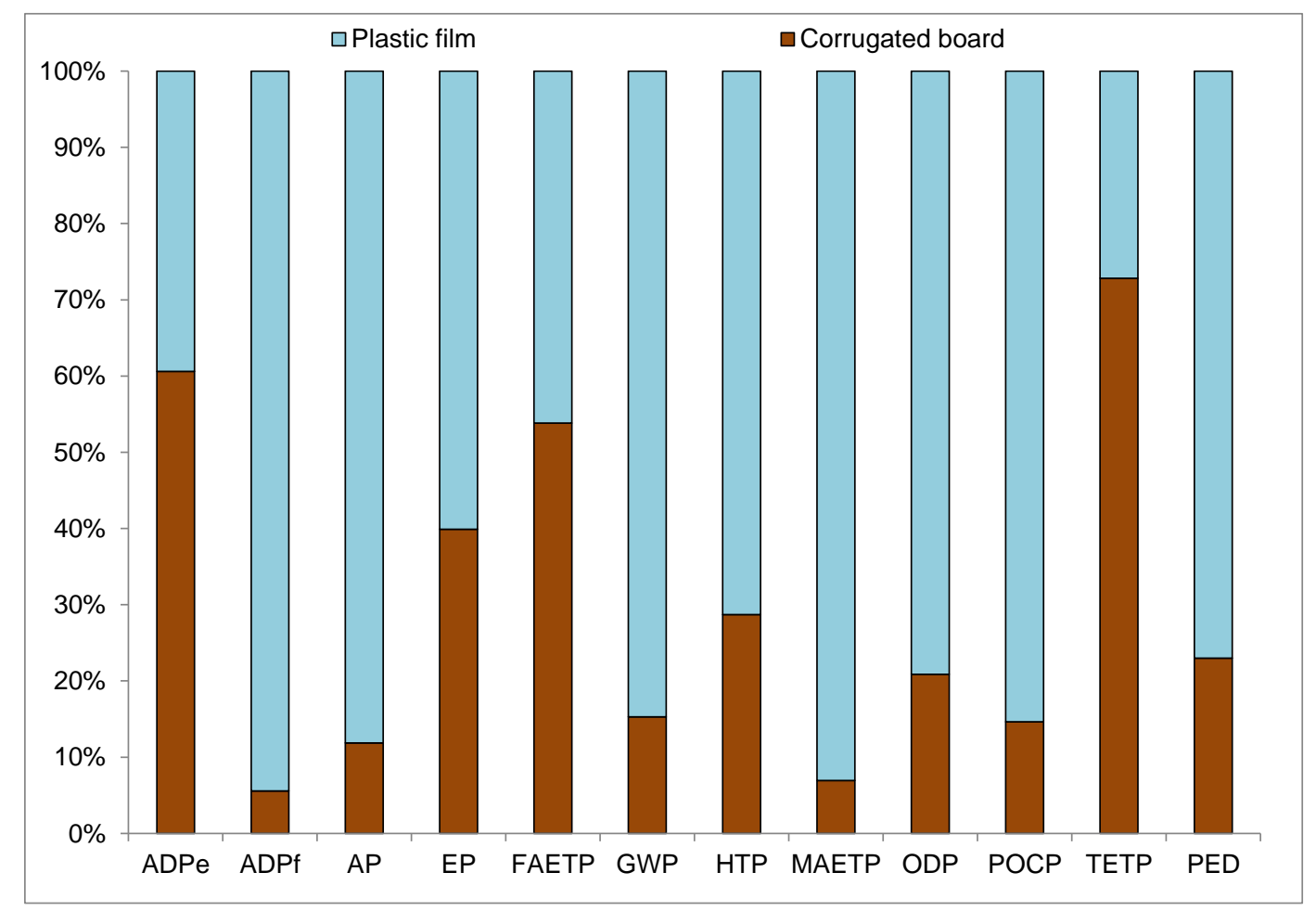

Figure $\mathbf{S 6}$ Contribution of packaging materials to environmental impacts [For the impacts nomenclature, see the footnote to Table S6.]

Table S7 Environmental impacts of the production of 1,000 standard and glueless diapers in the EU

\begin{tabular}{|c|c|c|c|}
\hline $\operatorname{Impacts}^{\mathrm{a}}$ & Standard & Glueless & $\begin{array}{c}\text { Savings from glueless } \\
\text { diapers (\%) }\end{array}$ \\
\hline $\mathrm{ADP}_{\mathrm{e}}$ (mg Sb eq.) & -60.0 & -46.6 & - \\
\hline $\mathrm{ADP}_{\mathrm{f}}(\mathrm{GJ})$ & 1.7 & 1.7 & 1.0 \\
\hline $\mathrm{AP}$ ( $\mathrm{g} \mathrm{SO}_{2}$ eq.) & 294.0 & 219.4 & 25.4 \\
\hline $\mathrm{EP}\left(\mathrm{g} \mathrm{PO}{ }^{3-}\right.$ eq. $)$ & 87.4 & 47.2 & 46.0 \\
\hline FAETP (kg eq.) & 3.9 & 1.5 & 62.1 \\
\hline GWP (kg CO 2 eq.) & 88.8 & 79.9 & 10.0 \\
\hline HTP (kg DBC eq.) & 13.3 & 5.4 & 59.8 \\
\hline MAETP (t DCB eq.) & 14.1 & 7.5 & 46.7 \\
\hline ODP ( $\mu$ R11 eq.) & 865.9 & 291.8 & 66.3 \\
\hline POCP ( $\left(\mathrm{g} \mathrm{C}_{2} \mathrm{H}_{4}\right.$ eq. $)$ & 33.1 & 28.1 & 15.1 \\
\hline TETP (g DCB eq.) & 241.9 & 227.9 & 5.8 \\
\hline PED (GJ) & 3.0 & 2.3 & 24.9 \\
\hline
\end{tabular}

${ }^{\mathrm{a}}$ For the impacts nomenclature, see Table S6.

Table S8 Total environmental savings in the EU through the implementation of glueless innovations over the period 2016-2020 for different market penetration of glueless diapers.

\begin{tabular}{|c|c|c|c|c|c|}
\hline Impacts & Market A & Market B & Market C & Market D & Market E \\
\hline $\mathrm{ADP}_{\mathrm{e}}[\mathrm{kg} \mathrm{Sb}$ eq.] & -46 & -183 & -371 & -606 & -860 \\
\hline $\mathrm{ADP}_{\mathrm{f}}[\mathrm{TJ}]$ & 59 & 237 & 480 & 784 & 1112 \\
\hline $\mathrm{AP}\left[\mathrm{t} \mathrm{SO} \mathrm{S}_{2}\right.$ eq. $]$ & 253 & 1010 & 2045 & 3340 & 4736 \\
\hline $\mathrm{EP}\left[\mathrm{t} \mathrm{PO}_{4}{ }^{3-}\right.$ eq. $]$ & 136 & 543 & 1099 & 1796 & 2546 \\
\hline FAETP [kt DCB eq.] & 8 & 33 & 66 & 108 & 153 \\
\hline GWP [kt $\mathrm{CO}_{2}$ eq.] & 30 & 121 & 245 & 399 & 566 \\
\hline HTP [kt DCB eq.] & 27 & 108 & 218 & 356 & 505 \\
\hline MAETP [Mt DCB eq.] & 22 & 89 & 180 & 294 & 417 \\
\hline ODP [kg R11 eq.] & 2 & 8 & 16 & 26 & 36 \\
\hline $\mathrm{POCP}\left[\mathrm{t} \mathrm{C}_{2} \mathrm{H}_{4}\right.$ eq. $]$ & 17 & 68 & 137 & 223 & 317 \\
\hline TETP [t DCB eq.] & 47 & 190 & 384 & 627 & 889 \\
\hline PED [PJ] & 3 & 10 & 20 & 33 & 47 \\
\hline
\end{tabular}

\footnotetext{
${ }^{a}$ Market A: poor uptake (5.3\% by 2020$)$, Market B: low uptake (21.2\%), Market C: moderate uptake (43.2\%), Market D: high uptake (70.2\%), Market E: very high uptake (100\%).
} 


\section{References}

ENTSO-E, 2015. Scenario Outlook and Adequacy Forecast (SO\&AF) 2014-2030 Dataset, European Network of Transmission System Operators for Electricity (ENTSO-E), Brussels.

ENTSO-E, 2016. ENTSO-E Yearly Statistics \& Adequacy Retrospect 2014. European Network of Transmission System Operators for Electricity (ENTSO-E), Brussels.

Euromonitor International, 2015. Tissue and Hygiene: Euromonitor from Trade Sources/National Statistics.

Eurostat, 2016. EUROSTAT Electricity and Heat Statistics. Supply, Transformation and Consumption of Heat - Annual Data. http://ec.europa.eu/eurostat/web/energy/data/database. 